\title{
New Insights in Purinergic Therapy: Novel Antagonists for UTP- Activated P2Y Receptors from Natural Products
}

Natiele Carla da Silva Ferreira (natiele-15@ hotmail.com) $^{1 *}$, Rômulo José Soares-Bezerra (cyentysta@gmail.com) ${ }^{1}$, Rebeca Ferreira Couto da Silveira (rebecafc.silveira@gmail.com) ${ }^{1}$, Clayton Menezes da Silva (claytom-menezes@ @otmail.com) ${ }^{1}$, Carla Santos de Oliveira (oliveirasc@yahoo.com.br) ${ }^{1}$, Andrea Surrage Calheiros (andrea.surrage@ gmail.com) ${ }^{2}$, Tânia Maria Alves (tania@minas.fiocruz.br) ${ }^{3}$, Carlos Leomar Zani (zani@minas.fiocruz.br) ${ }^{3}$, Luiz Anastacio Alves (alveslaa@gmail.com) ${ }^{1}$

${ }^{1}$ Laboratory of Cellular Communication, Oswaldo Cruz Institute, Oswaldo Cruz Foundation, Rio de Janeiro, RJ, Brazil - 21040-360; ${ }^{2}$ Laboratory of Immunopharmacology, Oswaldo Cruz Institute, Oswaldo Cruz Foundation, Rio de Janeiro, RJ, Brazil - 21040-360; ${ }^{3}$ Laboratory of Chemistry of Natural Products, René Rachou Research Center, Oswaldo Cruz Foundation, Belo Horizonte, MG, Brazil 30190-009.

*Corresponding author

\begin{abstract}
P2Y2 and P2Y4 receptors are physiologically activated by UTP and are widely expressed in many cell types in humans. They promote an increase in intracellular calcium via PLC $\beta / \mathrm{IP}_{3}$ and act on ion flux and water secretion. P2Y2 plays an important role in inflammation and proliferation of tumor cells, which could be attenuated with the use of antagonists. However, little is known about the physiological functions related to P2Y4 due to the lack of selective ligands for these receptors, which can be solved through the search of novel compounds with antagonistic activity. In the present study, we have applied a methodology of calcium measurement to identify new antagonist candidates for these receptors. Firstly, we established optimal conditions for calcium assay using J774.G8, a murine macrophage cell line, which expresses functional P2Y2 and P2Y4 receptors. J774.G8 cells were loaded with $2 \mu \mathrm{M}$ of Fluo-4 to test its sensitivity in responding calcium stimuli. ATP and ionomycin, known as inductors of intracellular calcium rise, were used to stimulate cells. The $\mathrm{EC}_{50}$ obtained were $11 \mu \mathrm{M}$ and $103 \mathrm{nM}$, respectively. Subsequently, investigation of P2Y2 and P2Y4 expression was performed. These cells responded with $\mathrm{EC}_{50}$ of $1.021 \mu \mathrm{M}$ to the UTP stimulation. Screening assays were performed and a total of 100 extracts from Brazilian natural products were tested. JA2, RA3, and RB3 extracts stood out for their ability to inhibit UTP-induced responses without causing cytotoxicity and presented $\mathrm{IC}_{50}$ of 32.32 $\mu \mathrm{g} / \mathrm{mL}, 14.99 \mu \mathrm{g} / \mathrm{mL}$, and $12.98 \mu \mathrm{g} / \mathrm{mL}$, respectively. Collectively, our results point to the discovery of potential antagonists candidates from natural products for UTPactivated receptors.
\end{abstract}

Keywords: P2Y, UTP, antagonist, natural products. 


\section{Introduction}

Purinergic receptors are plasma membrane receptors activated by extracellular purines and pyrimidines. These receptors are subdivided into two families, according to their main physiological ligand: P1 receptors, which are activated by adenosine, and P2 receptors, that are activated by nucleotides. P2 receptors are classified into two classes: ionotropic P2X receptors (P2XR) and metabotropic P2Y receptors (P2YR) [1].

P2YR receptors are G-protein coupled receptors that have eight subtypes cloned in mammals: P2Y1, P2Y2, P2Y4, P2Y6, P2Y11, P2Y12, P2Y13 and P2Y14 [1]. These subtypes are divided into two groups according to the signaling pathway promoted by G-protein. The P2Y1, P2Y2, P2Y4, P2Y6 and P2Y11 subtypes are coupled to Gqprotein and activate phospholipase $\mathrm{C} \beta$ (PLC $\beta$ ) that forms diacylglycerol (DAG) and inositol $1,4,5$,triphosphate $\left(\mathrm{IP}_{3}\right)$. $\mathrm{IP}_{3}$ induces an increase of intracellular calcium via IP3R activation in the endoplasmic reticulum. Meanwhile, P2Y12, P2Y13, and P2Y14 subtypes are coupled to $\mathrm{G}_{\mathrm{i}}$-protein and inhibit adenylyl cyclase (AC), causing a decrease in cyclic adenosine monophosphate (cAMP) formation [1,2].

$\mathrm{P} 2 \mathrm{Y} 2$ and P2Y4 receptors are physiologically activated by uridine triphosphate (UTP) and promote an increase in intracellular calcium via $\mathrm{PLC}_{3} \mathrm{IP}_{3}$ [2]. They are expressed in many cell types such as epithelial cells, monocytes, macrophages, neutrophils, cardiomyocytes and organs, including brain, heart, kidneys, liver, spleen, and muscle [3]. They have effects on chloride secretion in epithelial cells from airway and eyes, and they also induce water secretion in epithelial cells from the bowel. These functions are important to promote surface lubrification and mucus hydration, which can improve the treatment of diseases such as cystic fibrosis, dry eye disease and chronic constipation $[2,4]$. Recently, pharmaceutical companies have been applying efforts to search new P2Y2 agonists able to treat diseases associated with this receptor. As a result of these studies, Diquafosol ${ }^{\circledR}$ was implemented to treat dry eye disease, however, it is only approved in Japan and South Korea [5,6].

$\mathrm{P} 2 \mathrm{Y} 2 \mathrm{R}$ also has a role in neuroprotection, chemokinesis and in the proliferation of hepatocytes and tumor cells [7-10]. P2Y2 also is involved in the production of inflammatory modulators, such as COX-2 and PGE2, and neutrophil accumulation in lung and liver during inflammation [11-15]. Thus, P2Y2 antagonists might alleviate inflammation symptoms. 
P2Y4R participates in $\mathrm{Na}^{+}, \mathrm{K}^{+}$, and $\mathrm{Cl}^{-}$regulation processes, but its functions are not completely characterized because it is expressed in the same tissues and cell types that P2Y2R, where they are activated by the same physiological ligand, UTP [16-19]. Therefore, the lack of selective ligands impairs the discovery of new functions associated with these receptors. However, this problem can be solved with the search for novel compounds with antagonistic activity on P2Y2 and P2Y4 receptors.

Natural products are an important source for discovery of new molecules with antagonistic activity. They offer the vantage of millenary use in the treatment of several diseases, such as inflammation, parasitic, pain, and recently, cancer, constituting the basis of traditional oriental medicines [20-22]. Among the thirteen drugs approved for global marketing between 2005 and 2007, five were classified as natural products, while the others were semi-synthetic or derived, which reinforces its importance for clinical use [23]. In addition, it is already described in the literature that some biological species have compounds with antagonistic activity on P2 receptors, such as emodin from Rheum officinale Bail and amentoflavone from Rheedia longifolia Planch \& Triana on P2X7R [24,25]. However, due to a large number of samples for testing, implementation of high-throughput screening methodologies is necessary to meet this demand.

In this scenario, techniques of intracellular calcium measurement emerge as a tool for screening of new antagonists, since P2Y2 and P2Y4 receptors are coupled to calcium signaling pathway [26]. These methodologies have demonstrated importance in high-throughput screenings due to the advantage of evaluation of many compounds in a short period of time [27,28]. Kaulich et al. tested a series of forty flavonoids using calcium assays to discover novel lead antagonists for P2Y2R. They found that some flavonoids could inhibit P2Y2R and suggest the use of their structures to develop new compounds with antagonistic activity [29]. Recently, Ito et al. applied a protocol of intracellular calcium measurement in a high-throughput screening campaign to search novel antagonists for P2Y6 receptor and found one compound, TIM-38, with potential activity [30].

Thus, the aim of this study was to improve a protocol based on intracellular calcium measurement that allows the discovery of natural product compounds with antagonist activity on P2Y receptors activated by UTP. Firstly, we establish optimal conditions of protocol to execute the experiments using a cell line that express P2Y2 and P2Y4 receptors. After that, we performed a screening of a group of 100 extracts from natural products aiming at validating our protocol and discover possible hits. We 
found that nine extracts partly inhibited calcium mobilization in J774.G8 cell line, but only one significantly blocked this activity in peritoneal macrophages and did not present cytotoxicity. This natural extract may constitute a potential lead in the development of new antagonists for UTP-activated receptors.

\section{Results}

\section{1 - Establishment of a protocol for detection of intracellular calcium mobilization}

Our primary aim was to discover new antagonists for $\mathrm{P} 2 \mathrm{Y}$ receptors activated by UTP, so a protocol for detection of intracellular calcium mobilization was first established. We made a search in the literature to know concentrations of calcium indicator, Fluo-4, which were used in calcium assays and that could be applied in our protocol. We found in the literature a range of Fluo-4 used in calcium assays between 2 and $4 \mu \mathrm{M}$ [34-37]. In order to use low doses of dye, the first step was to optimize the concentration of Fluo-4 to our conditions of the assay, making it more economical to high throughput screening. In this context, we investigated concentrations ranging from 1 to $8 \mu \mathrm{M}$. We used ATP $[100 \mu \mathrm{M}]$ to stimulate the cells due to its activity as a main physiological P2 receptor agonist, which is widely expressed in J774.G8 cells. As observed in Figure 1A, there is no significant difference in the quantification of calcium response between concentrations between 1 to $4 \mu \mathrm{M}$. Concentrations of 6 and $8 \mu \mathrm{M}$ have significative difference only compared to $1 \mu \mathrm{M}$. Furthermore, our results are in a concentration range of Fluo-4 used in literature $(2-4 \mu \mathrm{M})$ [34-37]. A similar result was obtained with stimulation of cells with ionomycin, a calcium ionophore that promotes a massive transport of this ion from the extracellular to intracellular medium. All concentrations evaluated have the similar profile of quantification of calcium response (Figure 1B). Thus, the selected concentration of Fluo-4 to use in our experiments was of $2 \mu \mathrm{M}$ because calcium responses in this concentration did not differ from higher concentrations as well as being in literature range. As we could observe in Figure 1C, cells loaded with Fluo-4 at a concentration of $2 \mu \mathrm{M}$ show a homogenous dye scattering in their cytosol and after a stimulus with ionomycin, they become more fluorescence.

Next, two assays were performed to verify Fluo-4 sensibility in established concentration $(2 \mu \mathrm{M})$. Cells were stimulated with increasing concentrations of ATP and 
ionomycin and Fluo-4 fluorescence increased in a concentration-dependent manner, as shown in Figures $1 \mathrm{D}$ and $1 \mathrm{E} . \mathrm{EC}_{50}$ found for $\mathrm{ATP}$ and ionomycin were $11 \mu \mathrm{M}$ and 103 $\mathrm{nM}$, respectively. Therefore, in this primary step, we found that Fluo-4 concentration at $2 \mu \mathrm{M}$ was ideal for our assay since cells presented homogenous dye loading and sensibility to respond to calcium stimulus in increasing concentrations.

\section{Figure 1}

A

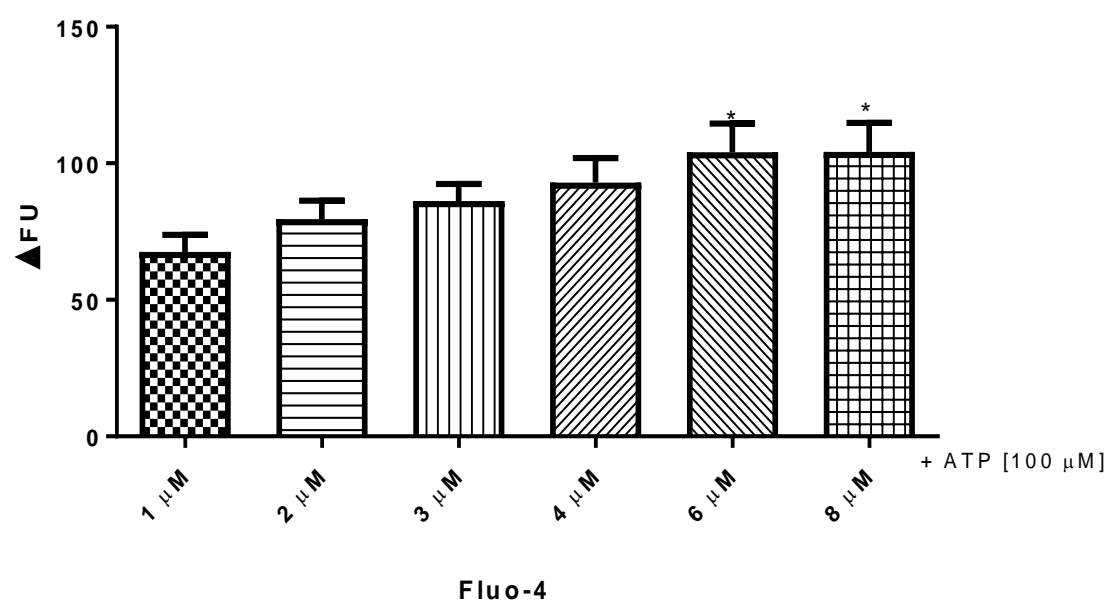

B

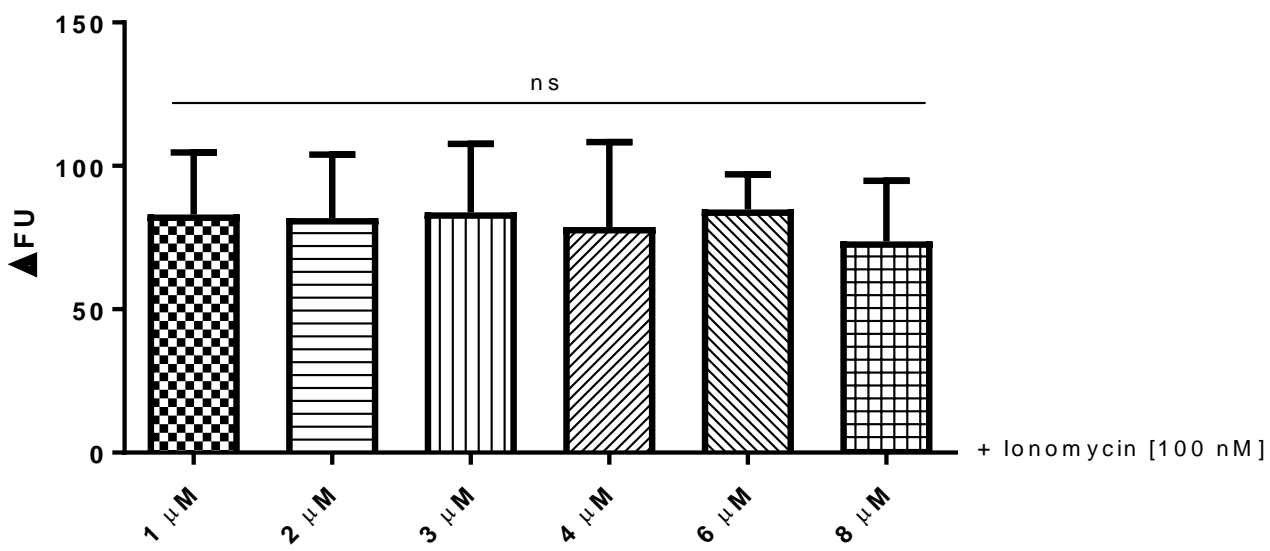

Flu o-4 
C

Bright field

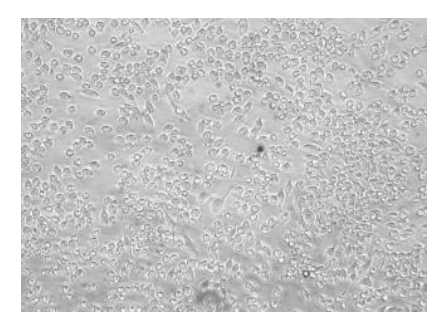

+ Ionomycin

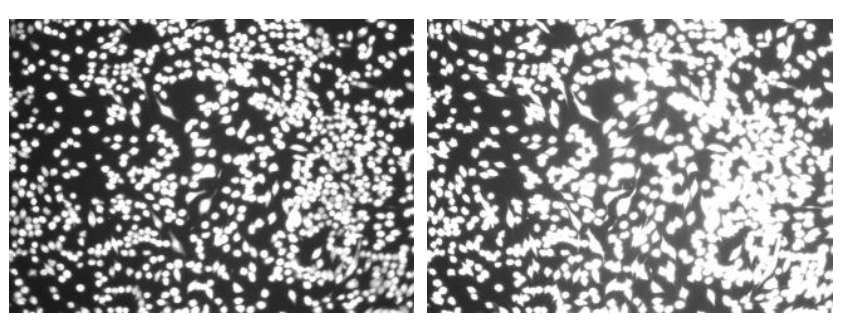

$\mathrm{D}$

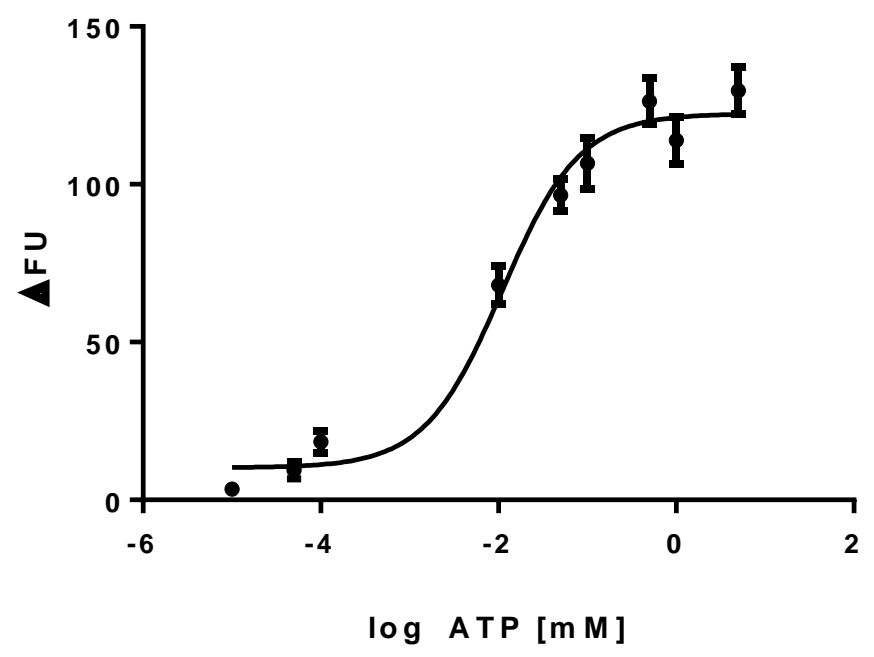

$\mathrm{E}$

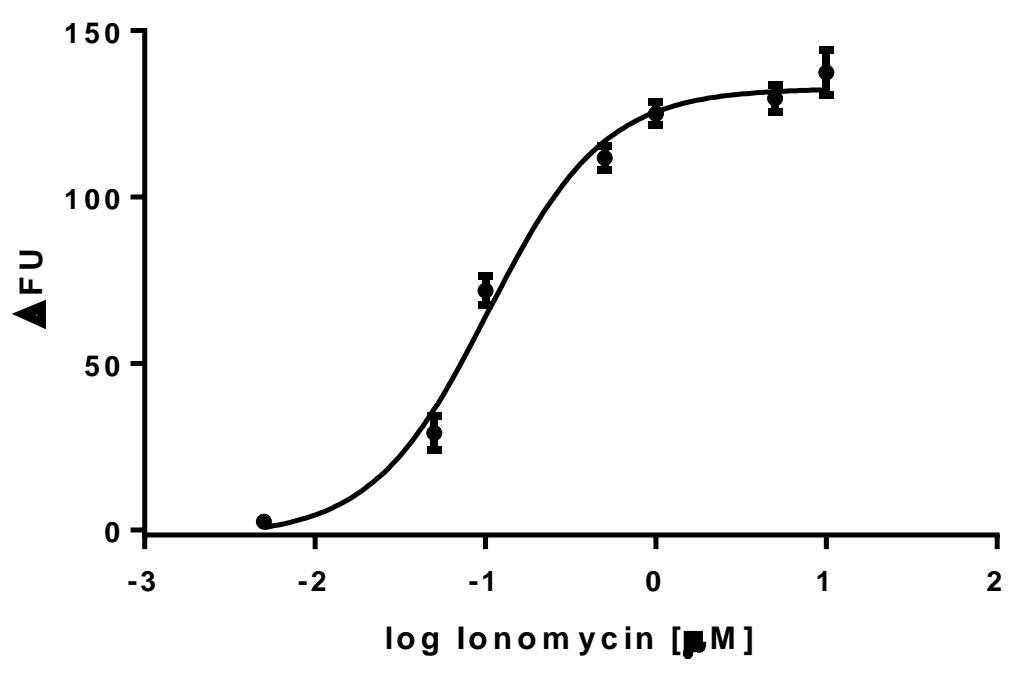




\section{Figure 1: Measurement of $\left[\mathrm{Ca}^{2+}\right]_{i}$ after ATP and ionomycin stimulation in cells} stained with Fluo-4. J774.G8 cells stained with different Fluo-4 concentrations were stimulated with $[100 \mu \mathrm{M}]$ ATP (A) and ionomycin $[100 \mathrm{nM}](\mathrm{B})$ and were monitored for 90 seconds on a FlexStation III equipment. Data are presented as Means \pm SDM of four independent experiments performed in triplicate. Data analysis were made using one-way ANOVA and Holm-Sidak post-test; $\mathrm{p}<0.05$. (*) indicates significant differences in relation to the $1 \mu \mathrm{M}$ concentration. (ns) means not significant. Observation of J774.G8 cells in bright field and fluorescence after loading with Fluo-4 and stimulated with ionomycin (objective 20x) (C). Representative images from three independent experiments performed in triplicate. ATP (D) and ionomycin (E) curves were obtained from J774.G8 cells stained with $2 \mu \mathrm{M}$ of Fluo-4. Data are presented as Means \pm SEM of three independent experiments performed in triplicate.

\section{2 - Assessment of quality of calcium responses induced by $\mathrm{P2}$ receptors}

In order to characterize the quality of calcium responses induced by $\mathrm{P} 2$ receptors through ATP stimulation acquired by FlexStation III, we analyzed original records. Original records showed that DPBS addition alone did not cause any signal variation, as expected (Figure 2A). ATP stimulus, on the other hand, increased intracellular calcium levels, which can be noted by fluorescence peak demonstrated in Figure 2B. This effect was reversed with the addition of EGTA, a calcium chelating agent, confirming that the fluorescence is associated with calcium, as shown in Figure 2C. Meanwhile, when cells were stimulated with ionomycin, they also increase their fluorescence (Figure 2D). However, it was not possible to observe a decline in intracellular levels during the selected time to perform this experiment, i.e., 90 seconds. More time probably will be required to observe this decline, which could decrease the number of wells read in a short period of time. Therefore, with these experiments, we validated our protocol of calcium measurement in FlexStation III.

\section{Figure 2}




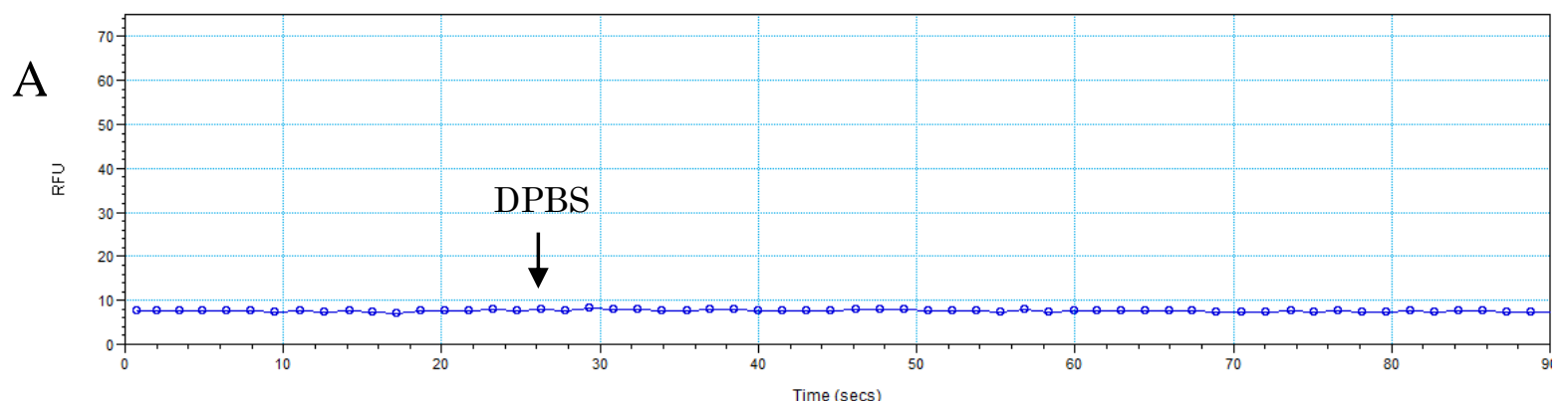

B

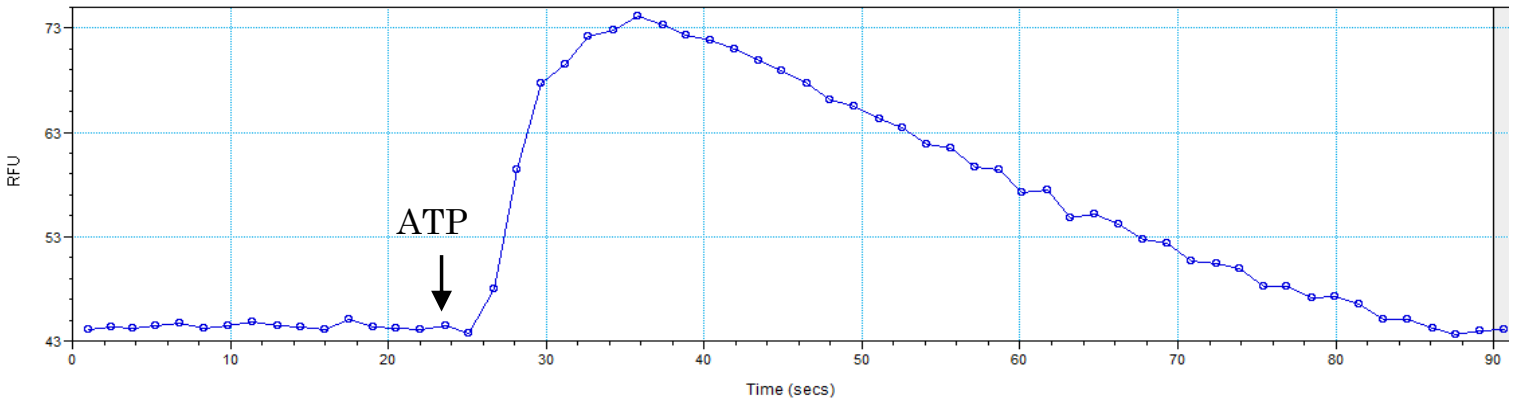

$\mathrm{C}$

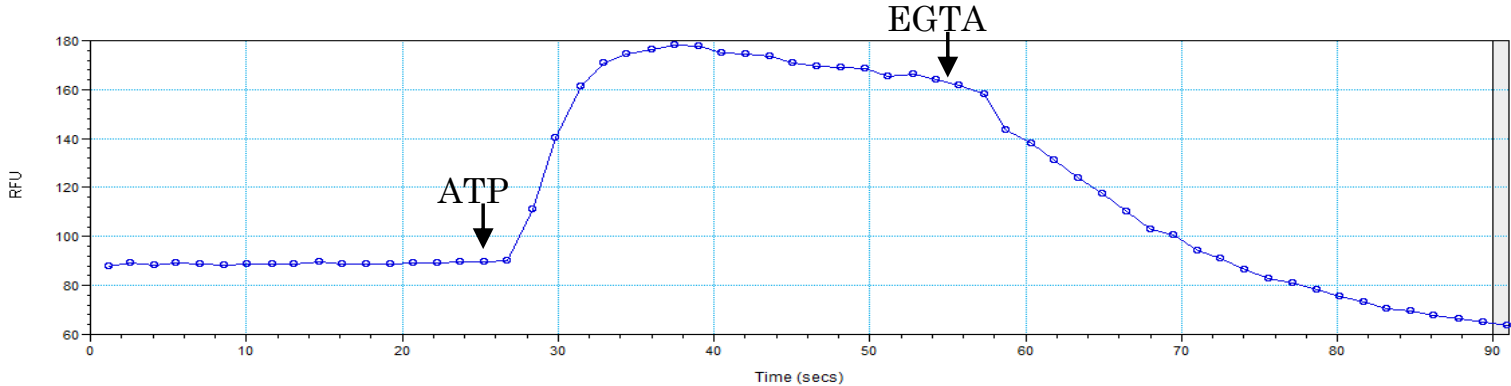

$\mathrm{D}$

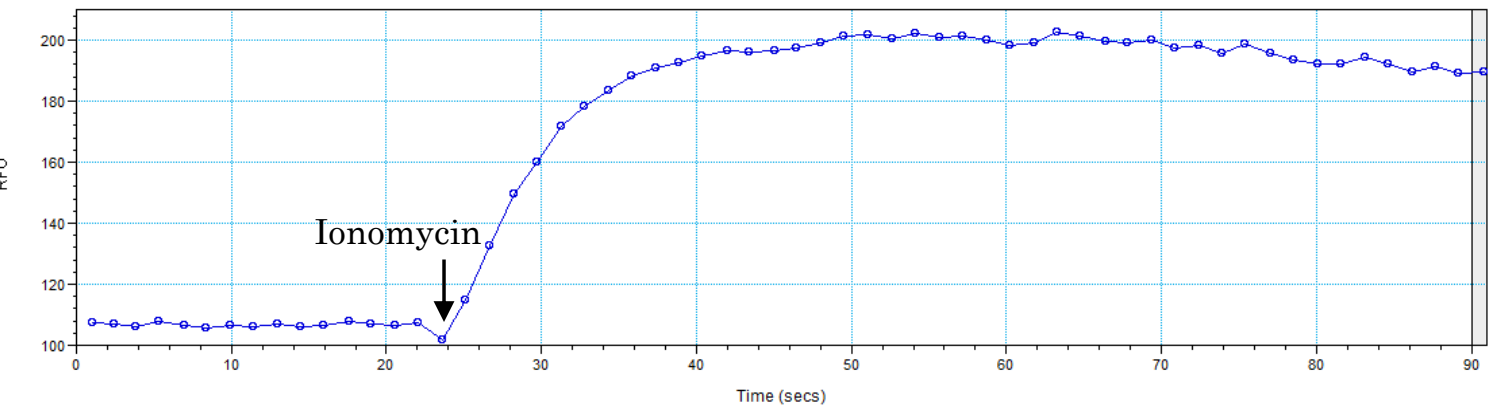

Figure 2: Original records of calcium signals obtained on a FlexStation III.

Original records of calcium signals obtained on a FlexStation III equipment after addition of $50 \mu \mathrm{l}$ of DPBS (A), ATP [100 $\mu \mathrm{M}$ ] (B and C) or Ionomycin (D) at 25 seconds and EGTA [20 mM] (54 seconds) (C) (indicated by the arrows) in J774.G8 cells stained with $2 \mu \mathrm{M}$ of Fluo-4. Representative images from three independent experiments performed in triplicate. 


\section{3 - Characterization of P2 receptors in J774.G8 cells}

Before starting the screening experiments, we attempted to identify which P2 receptors $(\mathrm{P} 2 \mathrm{R})$ were expressed in this cell line to guide our assay, avoiding bias, since some P2R subtypes were activated by the same agonists. Firstly, RT-PCR technique was performed aiming at verifying which P2R are expressed in J774.G8 cells. As seen in Figures 3A and B, cDNA fragments correspond to P2X1 (775 bp), P2X7 (186 bp), P2Y1 (683 bp), P2Y2 (850 bp), P2Y4 (544 bp), P2Y6 (480 bp), P2Y11 (274 bp) and P2Y12 (360 bp).

All these receptors, except the P2Y12R, are associated with signaling pathways of intracellular calcium increase via opening of a non-selective cation ion channel (P2X) or $\mathrm{PLC} \beta / \mathrm{IP}_{3}$ system activation $(\mathrm{P} 2 \mathrm{Y})$. Then, we investigated the response of $\mathrm{P} 2 \mathrm{R}$ subtypes expressed in J774.G8 cells using selective agonists. As shown in Figure 3C, this cell line expresses $\mathrm{P} 2 \mathrm{X}$ and $\mathrm{P} 2 \mathrm{Y}$ receptors, such as P2Y2 and P2Y4 activated by UTP, P2Y1, and P2Y6, which were activated by ADP and UDP, respectively. Cells also express $\mathrm{P} 2 \mathrm{X} 7$ that promotes calcium response since stimulation with BzATP (P2X7 selective agonist). ATP and $\alpha \beta$ meATP, non-selective agonists were used to observing general calcium responses of $\mathrm{P} 2$ and $\mathrm{P} 2 \mathrm{X}$ receptors, respectively. These results confirm expression of $\mathrm{P} 2$ receptors observed in RT-PCR, including UTP-activated P2Y receptors, i.e., P2Y2 and $\mathrm{P} 2 \mathrm{Y} 4$, which are our target subtypes. Interestingly, we observed that all agonists, with exception of ADP, present a lower response without extracellular calcium, which possible points participation of store-operated calcium channels. In case of ATP and $\alpha \beta$ meATP, this response could be ionotropic channels.

\section{Figure 3}

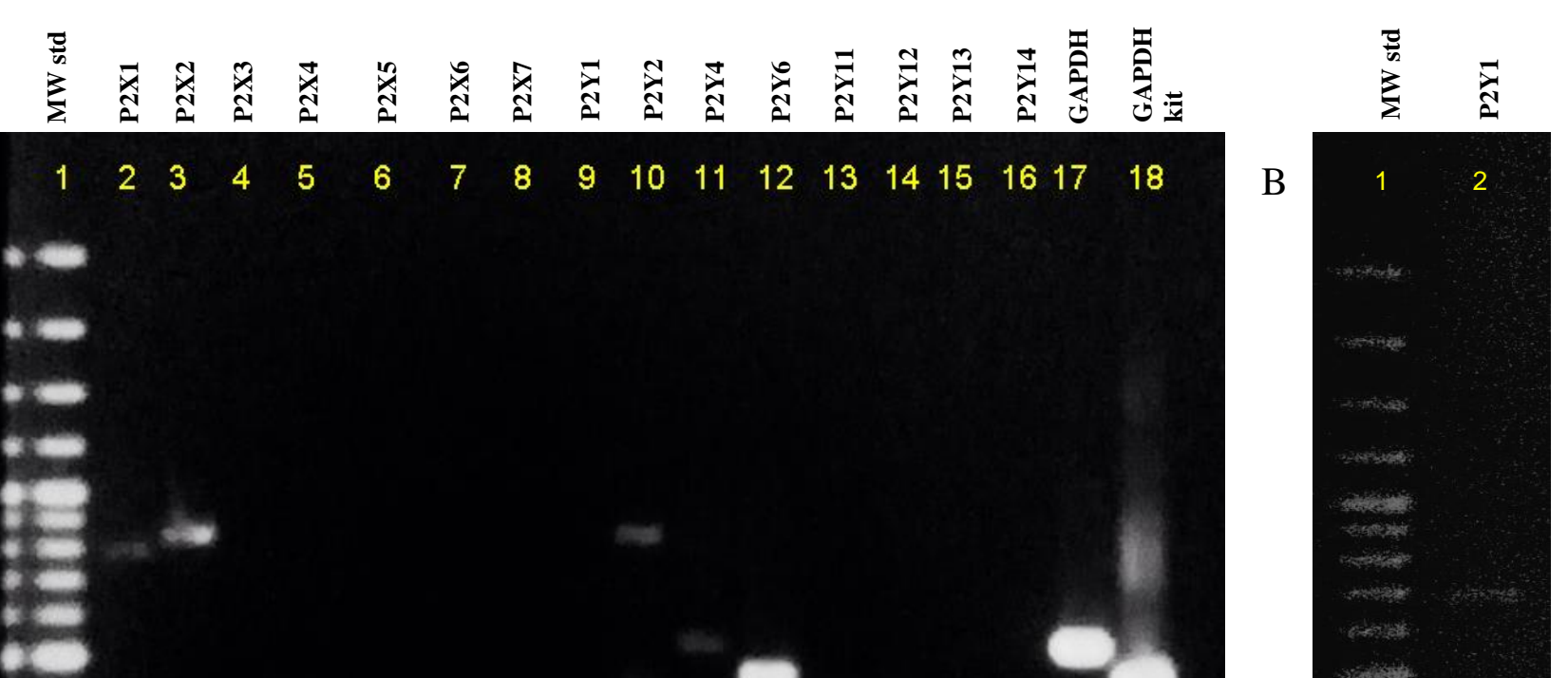




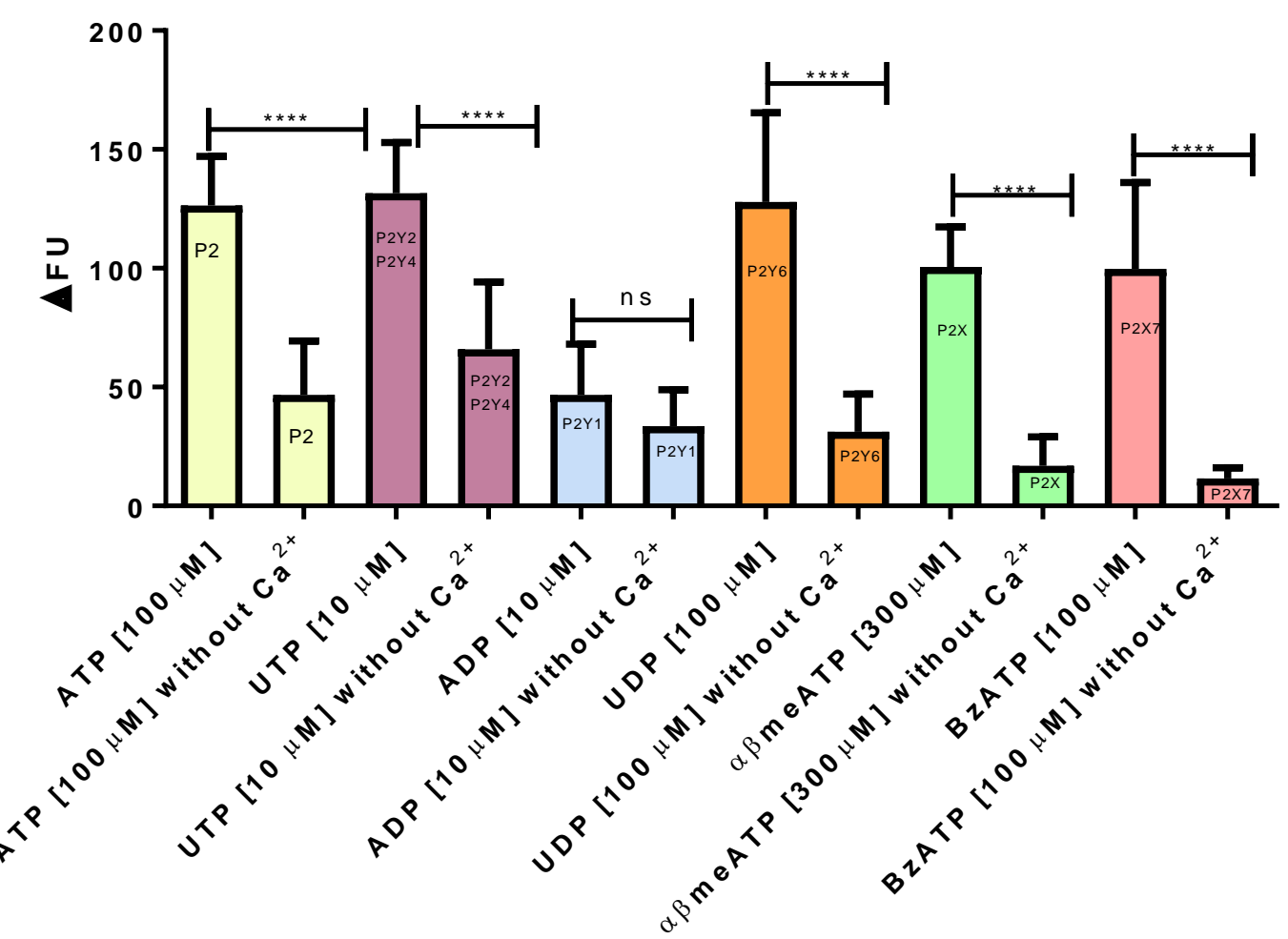

Figure 3: P2 receptors subtypes expressed in J774.G8 cell line. In (A), the columns correspond to cDNA fragments of subtypes described above them. MW std means molecular weight standard. Samples were run on $2 \%$ agarose gels and stained with ethidium bromide. Representative images from two experiments. In (C), increase of intracellular calcium induced by agonists of P2 receptors. Cells stained with $2 \mu \mathrm{M}$ of Fluo-4 were stimulated with ATP $[100 \mu \mathrm{M}]$, UTP $[10 \mu \mathrm{M}]$, ADP $[10 \mu \mathrm{M}], \alpha \beta$ meATP $[300 \mu \mathrm{M}]$ and BzATP $[100 \mu \mathrm{M}]$, and were monitored for 90 seconds. Data are presented as Means \pm SDM of three independent experiments performed in triplicate. Data analysis were made using one-way ANOVA and Holm-Sidak post-test; $p<0.05$. (*) indicates significant differences in relation to the respective group without $\mathrm{Ca}^{2+}$. (ns) means not significant. The receptors named inside bars correspond to subtypes activated by agonist used.

2.4 - Characterization of UTP-induced calcium responses and screening of natural products 
Since our cells express subtypes of UTP-activated receptors, i.e., P2Y2 and P2Y4, we stimulated them with increasing concentrations of this agonist to observe profile of UTP responses (Figure 4A). $\mathrm{EC}_{50}$ found was $1.021 \mu \mathrm{M}$. Next, we obtained the profile of $\mathrm{P} 2 \mathrm{Y} 2$ and $\mathrm{P} 2 \mathrm{Y} 4$ antagonists by performing an antagonism assay using Reactive-Blue 2 (RB2), Suramin and PPADS [2]. As shown in Figure 4B, RB2, Suramin, and PPADS partly inhibit UTP-induced intracellular calcium mobilization. To observe antagonistic profile of these inhibitors of $\mathrm{P} 2 \mathrm{Y} 2$ and $\mathrm{P} 2 \mathrm{Y} 4$ receptors, we pretreated cells with different concentrations of Suramin, RB2, and PPADS and we found $\mathrm{IC}_{50}$ of $173.3 \mu \mathrm{M}, 22.98 \mu \mathrm{M}$ and $74.24 \mu \mathrm{M}$, respectively (Figures 4C, D, E).

\section{Figure 4}

A

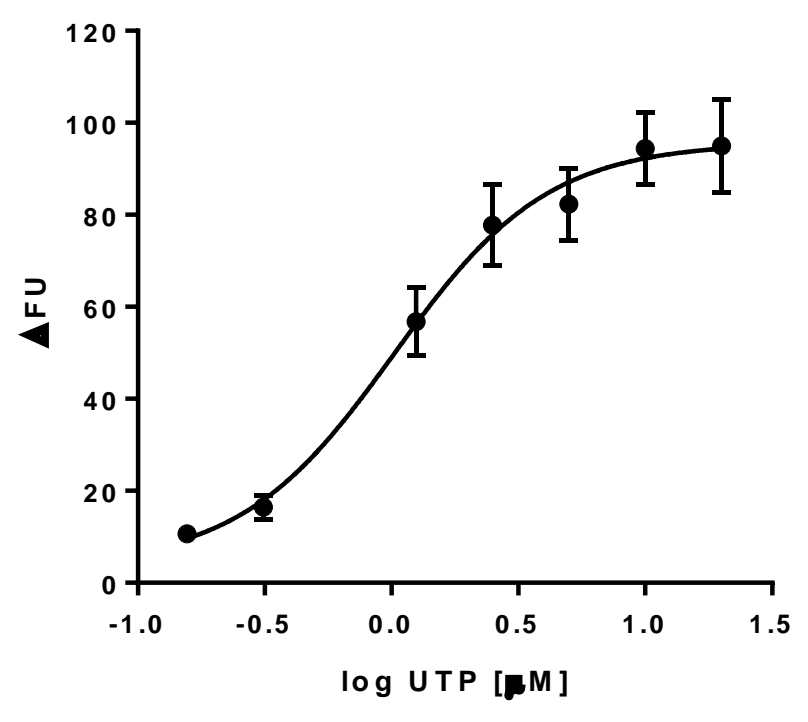




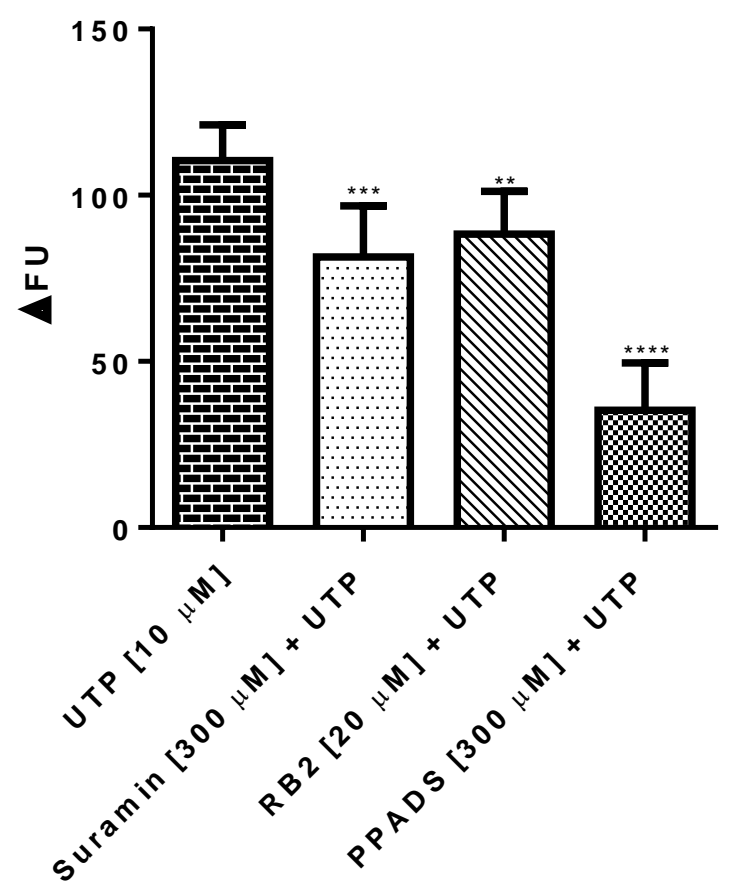

C

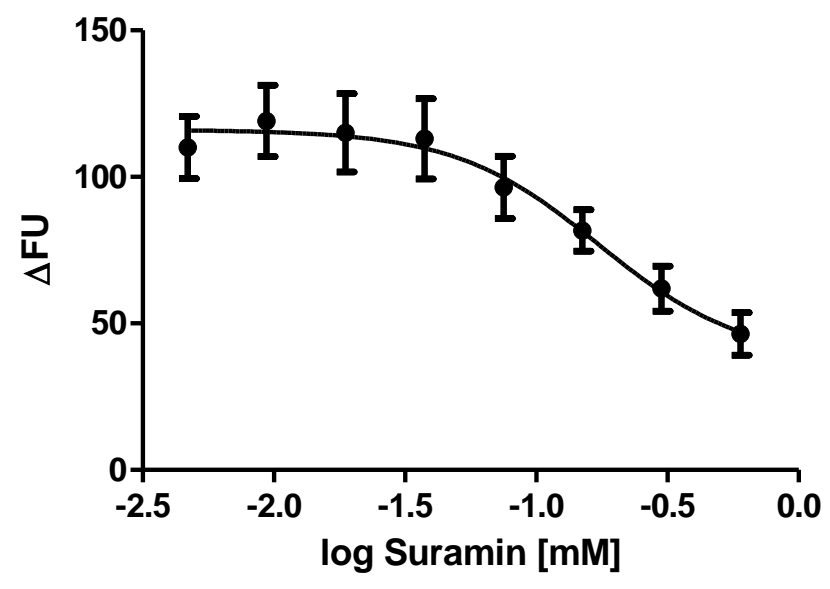

D 


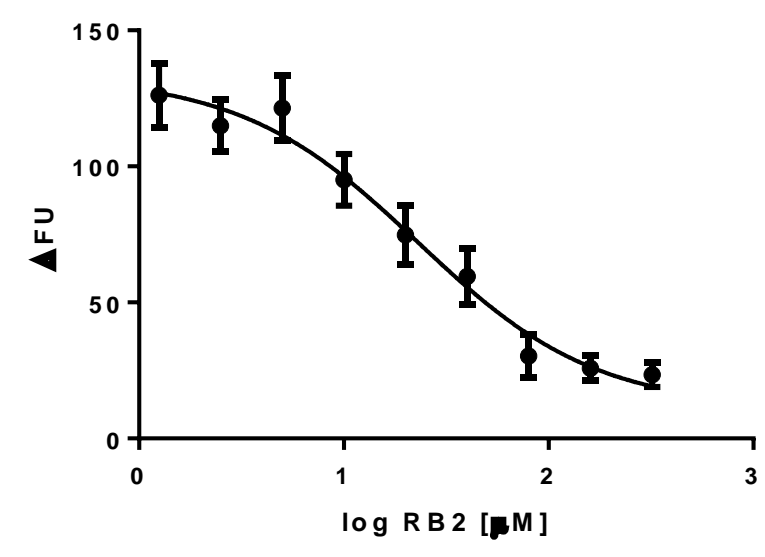

$\mathrm{E}$

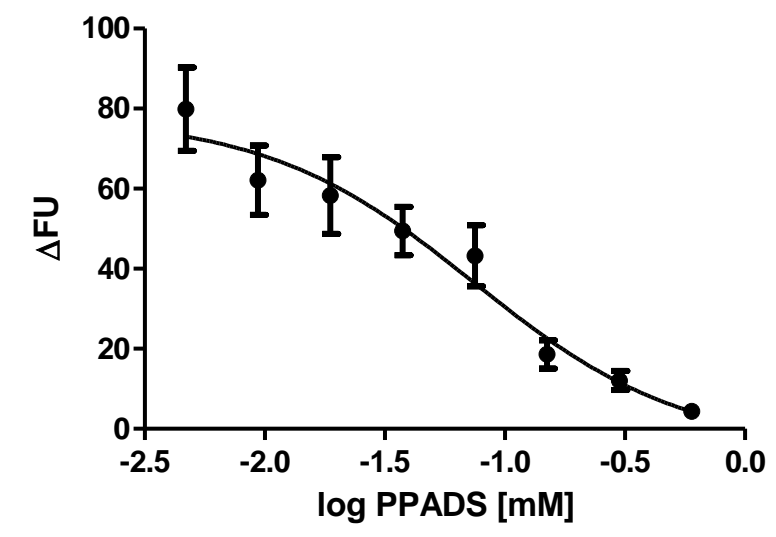

Figure 4: Calcium mobilization induced by UTP can be partially inhibited by P2Y2 and P2Y4 non-selective antagonists. UTP concentration-response curve was obtained from J774.G8 cells stained with $2 \mu \mathrm{M}$ of Fluo-4. Data are presented as Means \pm SEM of three independent experiments performed in triplicate (A). J774.G8 cells stained with $2 \mu \mathrm{M}$ of Fluo-4 were pretreated with Suramin [300 $\mu \mathrm{M}], \mathrm{RB} 2[20 \mu \mathrm{M}]$ and PPADS $[300 \mu \mathrm{M}]$ during 30 minutes. Cells were then stimulated with UTP [10 $\mu \mathrm{M}]$ and monitored for 90 seconds. Data are presented as Means \pm SDM of three independent experiments performed in triplicate. Data analysis were made using one-way ANOVA and Holm-Sidak post-test; $\mathrm{p}<0.05$. (*) indicates significant differences in relation to UTP (B). J774.G8 cells were pretreated with increasing concentrations of antagonists Suramin (C), RB2 (D) and PPADS (E) during 30 minutes, then were stimulated with UTP $[10 \mu \mathrm{M}]$. Data are presented as Means \pm SEM of four independent experiments performed in triplicate. 
After characterization of UTP calcium responses and inhibition profile of P2Y2 and P2Y4 antagonists, we calculated the z'-factor of our assay. Z'-factor is a statistical parameter used to measure the robustness of assays. We applied the mathematical equation of z'-factor and we obtained a value of 0.645 . Therefore, $z$ '-factor of our assay was above 0.5 and it is within the optimal range $\left(z^{\prime} \geq 0.5\right)$.

Finally, we performed the screening of 100 extracts from natural products, which data are summarized in Table 1. Nine extracts partially inhibited calcium mobilization induced by UTP: JA2, JA5, JB2, JB7, P2B6, P5C1, P5F3, RA3 and RB3. The same experiment was repeated using peritoneal macrophages from mice, a primary cell that expresses P2R. Using these cells, we observed that only JA2 extract was able to significantly inhibit UTP-calcium responses (Figure 5A). JA2 presented mean in peritoneal macrophages less than in J774.G8 (21.07 \pm 18.24 compared to $52.97 \pm$ 29.48), which could reflect differences between cell lines and primary cells. RA3 and RB3 extracts have not been tested in peritoneal macrophages due to sample scarcity. Then, cells were treated with increasing concentrations of JA2, RA3, and RB3 extracts and we found $\mathrm{IC}_{50}$ equal to $32.32 \mu \mathrm{g} / \mathrm{mL}, 14.99 \mu \mathrm{g} / \mathrm{mL}$, and $12.98 \mu \mathrm{g} / \mathrm{mL}$, respectively (Figures 5B, C, and D). Aiming at verifying if the inhibition of calcium responses would come from possible extracts cytotoxicity, tests of viability applying MTT technique were performed. As can be seen in Figure 5E, only RB3 extract caused a slight decrease in cell viability, but it did not be significative. Taking together, we characterized JA2, RA3, and RB3 extracts as potential antagonists candidates for UTPstimulated receptors. The next step is to characterize the active molecules from candidate extracts. 


\section{Figure 5}

A

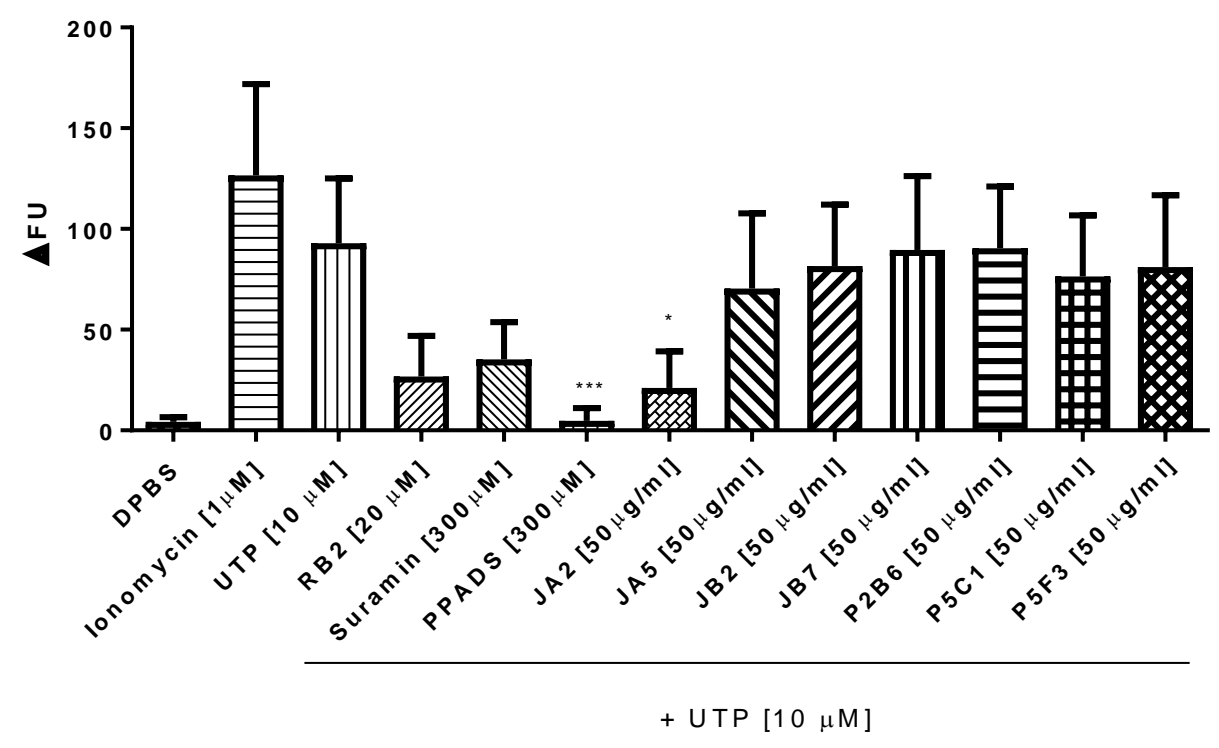

B

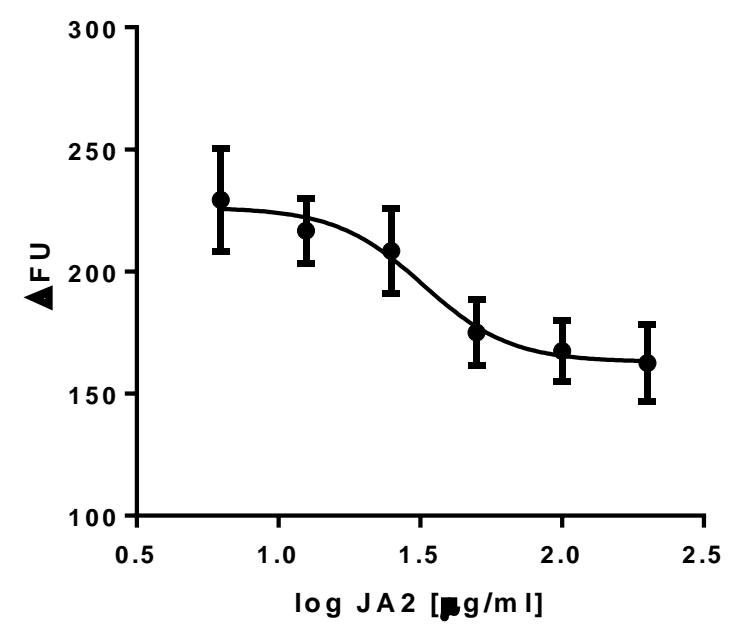


C

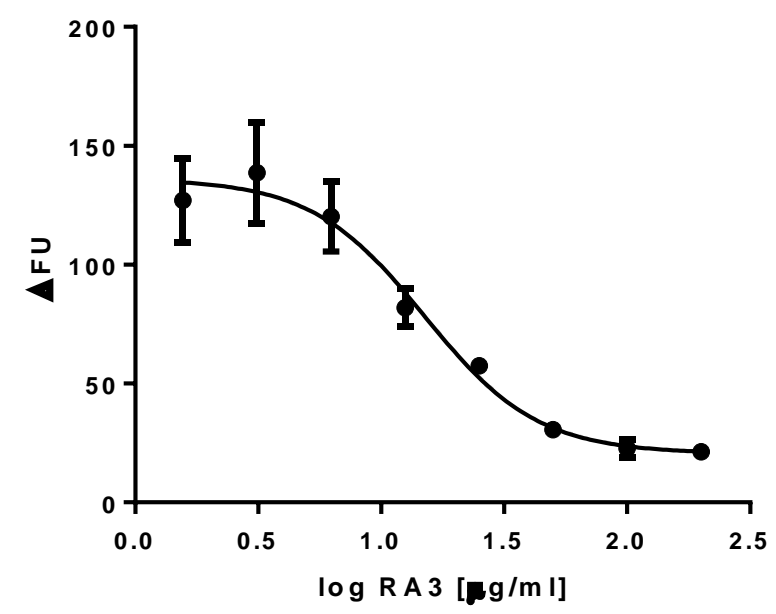

D

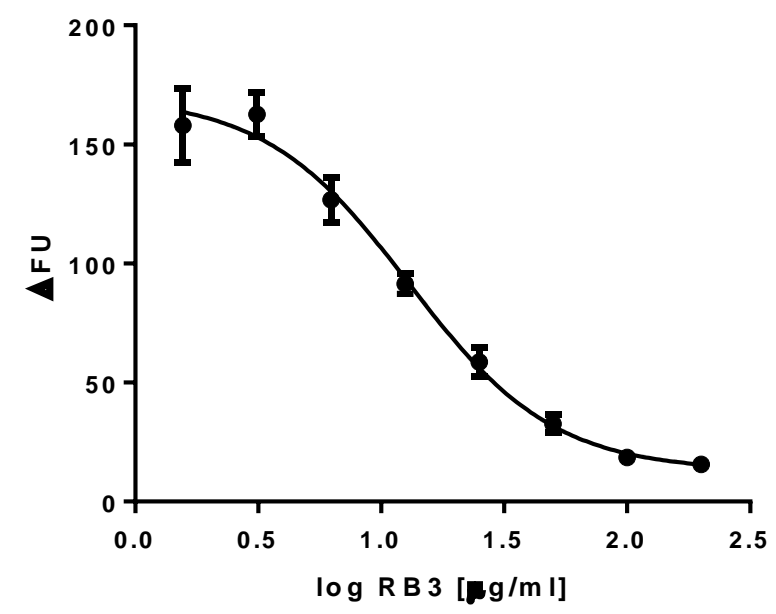

E

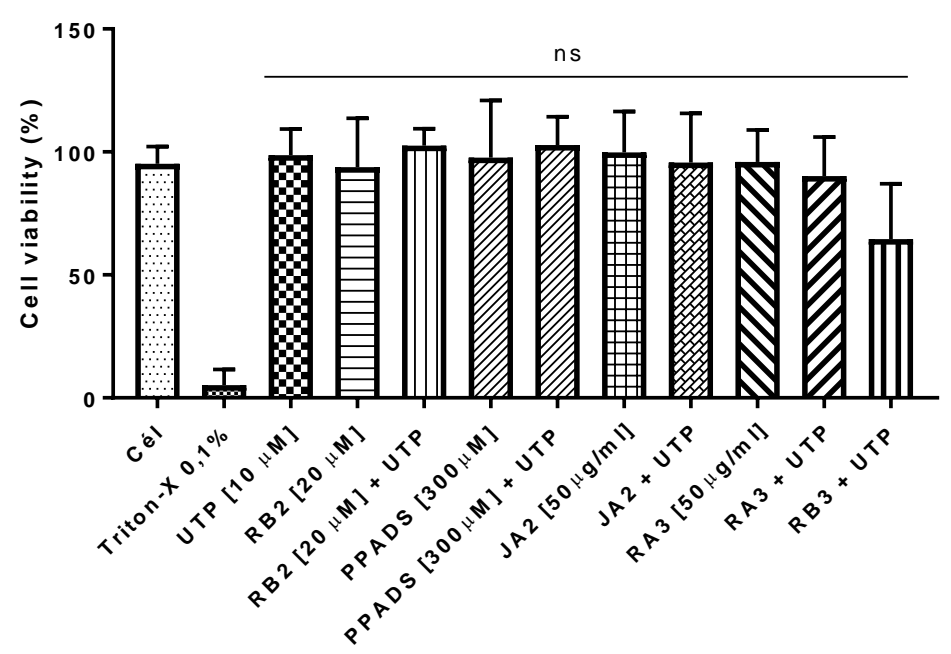




\section{Figure 5: JA2, RA3, and RB3 extracts partially inhibited calcium responses}

induced by UTP. Peritoneal macrophages stained with $2 \mu \mathrm{M}$ of Fluo- 4 were pretreated with RB2 $[20 \mu \mathrm{M}]$, Suramin $[300 \mu \mathrm{M}]$, PPADS [300 $\mu \mathrm{M}]$ and extracts [50 $\mu \mathrm{g} / \mathrm{mL}]$ during 30 minutes. Then, cells were stimulated with UTP $[10 \mu \mathrm{M}]$ and monitored for 90 seconds. Data are presented as Means \pm SDM of three independent experiments performed in triplicate. Data analysis were made using one-way ANOVA and Tukey post-test; $\mathrm{p}<0.05$. (*) indicates significant differences in relation to UTP (A). J774.G8 cells were pretreated with increasing concentrations of candidate extracts JA2 (B), RA3 (C) and RB3 (D) during 30 minutes, then were stimulated with UTP [10 $\mu \mathrm{M}]$. Data are presented as Means \pm SEM of four (B) and three (C and D) independent experiments performed in triplicate. J774.G8 cells were pretreated with RB2 [20 $\mu \mathrm{M}$ ], PPADS [300 $\mu \mathrm{M}]$ and JA2, RA3 and RB3 extracts $[50 \mu \mathrm{g} / \mathrm{mL}]$ in the presence or absence of UTP [10 $\mu \mathrm{M}$ ] during $1 \mathrm{~h}$. Then, cell viability was assessed by MTT technique (E). Data are presented as Means \pm SDM of three independent experiments performed in triplicate. Data analysis were made using one-way ANOVA and Tukey post-test; $p<0.05$. (*) indicates significant differences in relation to UTP. 
Table 1 - Effects of extracts from natural products on UTP-induced calcium mobilization

\begin{tabular}{|c|c|c|c|c|c|}
\hline Sample & $\Delta \mathrm{FU}$ mean $\pm \mathrm{SDM}$ & $\begin{array}{c}\Delta \mathrm{FU} \text { of control }(\mathrm{UTP}) \pm \\
\text { SDM }\end{array}$ & Sample & $\Delta \mathrm{FU}$ mean $\pm \mathrm{SDM}$ & $\begin{array}{c}\begin{array}{c}\Delta \mathrm{FU} \text { of control (UTP) } \\
\pm \mathrm{SDM}\end{array} \\
\end{array}$ \\
\hline A2 & $84.00 \pm 39.67$ & $136.3 \pm 22.41$ & F6 & $140.1 \pm 15.32$ & $131.1 \pm 17.41$ \\
\hline A3 & $96.11 \pm 34.83$ & $136.3 \pm 22.41$ & F9 & $131.4 \pm 19.00$ & $131.1 \pm 17.41$ \\
\hline A4 & $93.64 \pm 23.63$ & $136.3 \pm 22.41$ & G4 & $125.9 \pm 22.93$ & $131.1 \pm 17.41$ \\
\hline A5 & $121.50 \pm 26.98$ & $136.3 \pm 22.41$ & G6 & $116.6 \pm 34.57$ & $131.1 \pm 17.41$ \\
\hline A6 & $114.70 \pm 25.68$ & $136.3 \pm 22.41$ & H2 & $99.88 \pm 26.96$ & $131.1 \pm 17.41$ \\
\hline A7 & $118.20 \pm 25.61$ & $136.3 \pm 22.41$ & H7 & $120.60 \pm 26.54$ & $131.1 \pm 17.41$ \\
\hline A8 & $114.60 \pm 28.77$ & $136.3 \pm 22.41$ & H8 & $128.60 \pm 30.45$ & $131.1 \pm 17.41$ \\
\hline A9 & $103.80 \pm 19.04$ & $136.3 \pm 22.41$ & H9 & $122.50 \pm 24.30$ & $131.1 \pm 17.41$ \\
\hline $\mathbf{A 1 0}$ & $102.00 \pm 37.68$ & $136.3 \pm 22.41$ & H10 & $121.00 \pm 22.07$ & $131.1 \pm 17.41$ \\
\hline A11 & $90.91 \pm 23.84$ & $136.3 \pm 22.41$ & H11 & $118.80 \pm 25.45$ & $131.1 \pm 17.41$ \\
\hline B2 & $103.20 \pm 31.93$ & $136.3 \pm 22.41$ & JA2 & $52.97 \pm 29.48^{(* * *)}$ & $117.2 \pm 21.81$ \\
\hline B3 & $96.54 \pm 30.47$ & $136.3 \pm 22.41$ & JA4 & $87.34 \pm 17.22$ & $117.2 \pm 21.81$ \\
\hline B4 & $98.59 \pm 32.42$ & $136.3 \pm 22.41$ & JA5 & $69.73 \pm 12.95^{(* *)}$ & $117.2 \pm 21.81$ \\
\hline B5 & $104.40 \pm 31.61$ & $136.3 \pm 22.41$ & JA8 & $88.61 \pm 17.55$ & $117.2 \pm 21.81$ \\
\hline B6 & $112.00 \pm 32.86$ & $136.3 \pm 22.41$ & JA9 & $101.4 \pm 16.28$ & $117.2 \pm 21.81$ \\
\hline B7 & $101.30 \pm 42.64$ & $136.3 \pm 22.41$ & JA10 & $106.8 \pm 20.23$ & $117.2 \pm 21.81$ \\
\hline B8 & $101.10 \pm 45.63$ & $136.3 \pm 22.41$ & JA11 & $113.6 \pm 21.24$ & $117.2 \pm 21.81$ \\
\hline B9 & $79.80 \pm 32.15$ & $136.3 \pm 22.41$ & JB2 & $68.70 \pm 25.67^{(* *)}$ & $117.2 \pm 21.81$ \\
\hline B10 & $83.52 \pm 38.49$ & $136.3 \pm 22.41$ & JB3 & $103.3 \pm 22.15$ & $117.2 \pm 21.81$ \\
\hline B11 & $81.18 \pm 39.85$ & $136.3 \pm 22.41$ & JB4 & $83.31 \pm 15.39$ & $117.2 \pm 21.81$ \\
\hline $\mathrm{C2}$ & $97.98 \pm 28.62$ & $136.3 \pm 22.41$ & JB5 & $95.08 \pm 23.12$ & $117.2 \pm 21.81$ \\
\hline C3 & $86.42 \pm 33.81$ & $136.3 \pm 22.41$ & JB7 & $72.98 \pm 27.89^{(*)}$ & $117.2 \pm 21.81$ \\
\hline C4 & $84.02 \pm 32.69$ & $136.3 \pm 22.41$ & JB9 & $94.51 \pm 15.21$ & $117.2 \pm 21.81$ \\
\hline C5 & $89.70 \pm 32.30$ & $136.3 \pm 22.41$ & $\mathrm{JC4}$ & $80.44 \pm 21.36$ & $117.2 \pm 21.81$ \\
\hline C7 & $128.40 \pm 35.47$ & $136.3 \pm 22.41$ & JC7 & $104.4 \pm 23.61$ & $117.2 \pm 21.81$ \\
\hline $\mathrm{C8}$ & $114.90 \pm 34.39$ & $136.3 \pm 22.41$ & P2B6 & $88.47 \pm 7.95^{(* *)}$ & $133.0 \pm 24.81$ \\
\hline C9 & $123.10 \pm 23.62$ & $136.3 \pm 22.41$ & P5C1 & $90.14 \pm 19.28^{(*)}$ & $133.0 \pm 24.81$ \\
\hline C10 & $126.30 \pm 16.57$ & $136.3 \pm 22.41$ & P5F3 & $94.78 \pm 26.75^{(*)}$ & $133.0 \pm 24.81$ \\
\hline C11 & $129.20 \pm 16.79$ & $136.3 \pm 22.41$ & RA2 & $47.18 \pm 72.71$ & $99.71 \pm 62.55$ \\
\hline D2 & $130.90 \pm 16.78$ & $136.3 \pm 22.41$ & RA3 & $11.15 \pm 10.11^{(* *)}$ & $99.71 \pm 62.55$ \\
\hline D3 & $121.60 \pm 21.87$ & $136.3 \pm 22.41$ & RA4 & $126.00 \pm 41.12$ & $99.71 \pm 62.55$ \\
\hline D4 & $128.00 \pm 20.63$ & $136.3 \pm 22.41$ & RA5 & $121.10 \pm 47.06$ & $99.71 \pm 62.55$ \\
\hline D5 & $119.90 \pm 26.90$ & $136.3 \pm 22.41$ & RA6 & $92.82 \pm 38.43$ & $99.71 \pm 62.55$ \\
\hline D6 & $101.00 \pm 36.11$ & $136.3 \pm 22.41$ & RA7 & $64.31 \pm 19.61$ & $99.71 \pm 62.55$ \\
\hline D7 & $98.50 \pm 21.90$ & $136.3 \pm 22.41$ & RA8 & $101.40 \pm 34.38$ & $99.71 \pm 62.55$ \\
\hline D8 & $111.70 \pm 28.66$ & $136.3 \pm 22.41$ & RA9 & $105.90 \pm 26.27$ & $99.71 \pm 62.55$ \\
\hline D9 & $123.80 \pm 11.76$ & $136.3 \pm 22.41$ & RA10 & $100.80 \pm 39.60$ & $99.71 \pm 62.55$ \\
\hline D10 & $109.60 \pm 21.55$ & $136.3 \pm 22.41$ & RA11 & $117.30 \pm 30.47$ & $99.71 \pm 62.55$ \\
\hline D11 & $127.00 \pm 36.18$ & $136.3 \pm 22.41$ & RB2 & $51.19 \pm 27.55$ & $99.71 \pm 62.55$ \\
\hline E2 & $117.40 \pm 20.61$ & $142.0 \pm 18.04$ & RB3 & $19.96 \pm 31.03^{(* *)}$ & $99.71 \pm 62.55$ \\
\hline E3 & $103.20 \pm 18.34$ & $142.0 \pm 18.04$ & RB4 & $106.90 \pm 32.81$ & $99.71 \pm 62.55$ \\
\hline E4 & $102.30 \pm 47.03$ & $142.0 \pm 18.04$ & RB5 & $85.30 \pm 15.44$ & $99.71 \pm 62.55$ \\
\hline E5 & $100.10 \pm 36.62$ & $142.0 \pm 18.04$ & RB6 & $110.50 \pm 37.21$ & $99.71 \pm 62.55$ \\
\hline E6 & $95.00 \pm 36.32$ & $142.0 \pm 18.04$ & RB7 & $110.80 \pm 36.12$ & $99.71 \pm 62.55$ \\
\hline E7 & $91.00 \pm 41.39$ & $142.0 \pm 18.04$ & RB8 & $97.02 \pm 29.97$ & $99.71 \pm 62.55$ \\
\hline E8 & $115.30 \pm 41.97$ & $142.0 \pm 18.04$ & RB9 & $114.70 \pm 37.33$ & $99.71 \pm 62.55$ \\
\hline E9 & $108.00 \pm 45.52$ & $142.0 \pm 18.04$ & RB10 & $91.47 \pm 35.80$ & $99.71 \pm 62.55$ \\
\hline E10 & $129.80 \pm 45.93$ & $142.0 \pm 18.04$ & RB11 & $99.84 \pm 51.68$ & $99.71 \pm 62.55$ \\
\hline E11 & $91.27 \pm 30.64$ & $142.0 \pm 18.04$ & RC2 & $60.97 \pm 23.75$ & $99.71 \pm 62.55$ \\
\hline F2 & $132.1 \pm 23.55$ & $131.1 \pm 17.41$ & RC3 & $59.46 \pm 21.70$ & $99.71 \pm 62.55$ \\
\hline
\end{tabular}

J774.G8 cells labeled with $2 \mu \mathrm{M}$ Fluo-4 were pretreated with Suramin [300 $\mu \mathrm{M}], \mathrm{RB} 2$ $[20 \mu \mathrm{M}]$ and extracts $[50 \mu \mathrm{g} / \mathrm{mL}]$ for 30 minutes. Then, cells were stimulated with UTP 
$[10 \mu \mathrm{M}]$, Ionomycin $[1 \mu \mathrm{M}]$ and $0.5 \%$ DMSO and monitored for 90 seconds. Mean \pm SDM of three independent experiments. Data analysis were made using one-way ANOVA and Tukey post-test; $\mathrm{p}<0.05$. $\left(^{*}\right)$ indicates significant differences in relation to UTP.

\section{Discussion}

P2Y2 and P2Y4 are purinergic receptors physiologically activated by UTP, which promote an increase of intracellular calcium via PLC $\beta / \mathrm{IP}_{3}$ when activated [2]. They are expressed in many cell types such epithelial cells and leukocytes, and even in organs such as brain, heart, kidneys, liver, spleen, and muscle [3], where they play important roles. Likewise, these $\mathrm{P} 2 \mathrm{Y}$ receptors are associated with certain diseases such as cystic fibrosis, dry eye disease, Alzheimer, and cancer $[2,4,7]$. Thus, pharmaceutical companies have been developing drugs that act on these $\mathrm{P} 2 \mathrm{Y}$ receptors, especially $\mathrm{P} 2 \mathrm{Y} 2$, in order to treat these related diseases $[5,6,38]$. However, the lack of selective ligands that act on $\mathrm{P} 2 \mathrm{Y} 2$ and $\mathrm{P} 2 \mathrm{Y} 4$ receptors compromises the discovery of new functions associated with these receptors, which can be solved by the search of new antagonist compounds [19]. Therefore, the aim of this study was to improve a methodology for the detection of intracellular calcium mobilization to discover new molecules with antagonistic activity on UTP-activated P2Y receptors. For this reason, we established a protocol to evaluate intracellular calcium mobilization.

First, the concentration of calcium indicator Fluo-4 was optimized. Fluo-4 is widely used in high-throughput screening assays of metabotropic receptors that induce an increase of intracellular calcium [39]. We chose a $2 \mu \mathrm{M}$ concentration because of the apparent homogenous cellular loading in cells and due to the fact that there were no significant differences between it and other concentrations. In addition, it is important to use the lowest concentration that results in a good signal, thereby reducing reagent consumption and expenses during screening [33]. Gee and coworkers (2000) also demonstrated that the use of the lowest concentrations of calcium indicators can reduce the buffer effect on calcium, as well as minimize the levels of toxic products such as formaldehyde and acetic acid, which are produced through the hydrolysis of acetoxymethyl esters [40]. Furthermore, by using this concentration we demonstrated that cells were able to react to different stimuli that increase intracellular calcium levels 
in a concentration-dependent manner, such as agonists of P2R, including ATP and UTP. The $\mathrm{EC}_{50}$ found for ATP $(11 \mu \mathrm{M})$ is a little higher than found by Li and coworkers (2008) when they performed calcium experiments in FlexStation III: $1.1 \mu \mathrm{M}$ and $58 \mathrm{nM}$ for Hek 293 and CHO-K1 cells, respectively [39]. This could be a sum of response from various P2R that could be activated by ATP such as P2Y2, P2Y11, P2X1, P2X2 and P2X7 subtypes. The latter could have displaced the $\mathrm{EC}_{50}$ since its activation occurs in concentrations higher than $100 \mu \mathrm{M}$. Meanwhile, $\mathrm{EC}_{50}$ found for ionomycin $(103 \mathrm{nM})$ was lower than that obtained by Valentin et al. (2011), i.e., 1.5, $\mu \mathrm{M}$ when they performed calcium assay on microplate reader with human endothelial cells of the umbilical vein (Huvec) [41].

We also observed some expected characteristics of calcium signals, such as the uniformity of the basal signal, the peak of the signal after ATP stimulus, indicating an increase of $\left[\mathrm{Ca}^{2+}\right]_{i}$ and the return of this signal to basal level after response time, which in calcium events usually occurs in seconds. In addition, a decrease of calcium responses in the presence of EGTA, a calcium chelating agent, was also observed. A similar response profile was obtained through calcium imaging (data not shown). Ionomycin stimulation also induced an increase in intracellular calcium levels, but during the period of measurement of the experiment (90 seconds), it was not possible to observe the return to basal levels. However, longer time of measurement of ionomycin response could be required to observe this return. But increasing the time of wells measurement could cause a diminution in a number of samples read in an established period of time. Therefore, we opted to maintain the set time for 90 seconds. Moreover, we calculated z'-factor, a measure of robustness of assay, and we found a value of 0.645, which indicates that our protocol was adequate for use. Ito and coworkers (2017) performed a high-throughput screening assay to identify novel antagonists for P2Y6R using P2Y6-1321N1 cells and obtained a z'-factor of 0.80 [30]. Valentin et al. (2011) used primary cells (Huvec) to perfume high-throughput screening based on calcium measurement and obtained a z'-factor of 0.60 [41]. These findings suggest that use of transfected cells could improve the performance of the assay. However, the use of transfected cells can add a cost to screening, and therefore it is suggested that it is used in a second moment in order to verify the response of hits. Taken together, these evaluated characteristics suggest that our protocol was appropriated for use.

The next step was identifying if J774.G8 murine macrophage cell line express P2Y-activated by UTP, which were targets of the screening assay. Using RT-PCR 
technique, we detected cDNA for P2X1, P2X2, P2X7, P2Y1, P2Y2, P2Y4, P2Y6, P2Y11 and P2Y12 subtypes. These P2R subtypes have been described in macrophages in many studies applying molecular and pharmacological methods [42-45]. Furthermore, all these receptors are associated with signaling pathways of intracellular calcium increases via the opening of a non-selective cation ion channel (P2X) or $\mathrm{PLC} \beta / \mathrm{IP}_{3}(\mathrm{P} 2 \mathrm{Y})$, with exception of P2Y12. Therefore, we characterized these subtypes using the following agonists: ATP, a non-selective P2 receptor agonist, UTP, a P2Y2 and $\mathrm{P} 2 \mathrm{Y} 4$ receptors agonist, ADP for $\mathrm{P} 2 \mathrm{Y} 1$ receptor, UDP for $\mathrm{P} 2 \mathrm{Y} 6$ receptor, BzATP, a selective agonist of $\mathrm{P} 2 \mathrm{X} 7$ and $\alpha \beta \mathrm{meATP}$ for $\mathrm{P} 2 \mathrm{X}$ receptors. These data showed functional expression of these receptors. The calcium responses decreased in absence of extracellular calcium, which suggests the participation of store-operated calcium channels and ionotropic receptors in amplification of intracellular calcium mobilization [46].

Then, we obtained the profile of P2Y2 and P2Y4 agonist UTP and antagonists (Suramin, RB2, and PPADS). J774.G8 cells were stimulated with increasing concentrations of UTP and we found an $\mathrm{EC}_{50}$ of $1.021 \mu \mathrm{M}$. It is similar to that cited by King and coworkers (1998): $1.1 \mu \mathrm{M}$ for P2Y2 and $0.20 \mu \mathrm{M}$ for P2Y4 receptors [47]. In relation to the antagonists, we observed that Suramin and RB2 partially block the intracellular UTP-induced calcium mobilization. King et al. (1998) cited that PPADS $(100 \mu \mathrm{M})$ and RB2 $(100 \mu \mathrm{M})$ inhibited approximately $30 \%$ of P2Y4R, while Suramin is ineffective $[47,48]$. Von Kügelgen (2006) cited that P2Y2 is blocked by Suramin and RB2, but not by PPADS [48]. We also hypothesize that participation of store-operated calcium channels could have influenced some level of their inhibition.

It is worth mentioning that our work was one of the pioneers in the search for novel antagonists using natural products, which present a diversity in a number of species and chemical structures, both acquired over millions of years of evolution. Thus, we tested one hundred extracts from a natural library at a cut-off concentration, established at $50 \mu \mathrm{g} / \mathrm{mL}$. At first, nine extracts demonstrated a partial inhibition of UTPinduced calcium responses in J774.G8 cells. After repeat this experiment with a primary cell, i.e., peritoneal macrophages, that express P2Y2 and P2Y4 receptors [44], we found that only JA2 extract inhibit this activity. Other two extracts were not tested in these cells due to sample scarcity. However, aiming at observing the occurrence of this inhibition at higher doses, we treated J774.G8 cells with increasing concentrations of extracts. Calcium responses were inhibited in a concentration-dependent manner, 
suggesting its potential ability to block UTP-activated P2Y receptors. We asked if this inhibition could be due to cell toxicity. To answer this question, we performed a cell viability assay applying MTT technique and observed that they did not promote cytotoxicity.

Collectively, our results point to the discovery of potential antagonists from natural products for $\mathrm{P} 2 \mathrm{Y} 2$ and $\mathrm{P} 2 \mathrm{Y} 4$ receptors, which may significantly contribute to purinergic pharmacology.

\section{Materials and Methods}

\section{1 - Reagents}

Chemicals were purchased from Sigma Chemical Co. (St. Louis, Missouri, USA), including ATP, UTP, ADP, UDP, $\alpha \beta$-meATP, Suramin, DMEM and RPMI culture mediums, $\mathrm{NaCl}, \mathrm{KCl}, \mathrm{Na}_{2} \mathrm{HPO}_{4}, \mathrm{KH}_{2} \mathrm{PO}_{4}, \mathrm{MgCl}_{2}, \mathrm{CaCl}_{2}$, Glucose, DMSO, MTT ( (3-(4,5-dimethylthiazol-2-yl)-2,5-diphenyltetrazolium bromide) tetrazolium, Probenecid and Ionomycin. Fetal bovine serum was obtained from Cultilab (Campinas, SP, Brazil) and Fluo-4 AM was obtained from Life Technologies (California, USA).

\section{2 - Extracts}

Extracts used in this work were collected from Brazilian biomes (Amazon, Cerrado, Caatinga, Atlantic Forest, Pantanal, and Pampas) and were obtained through extraction with methanol. They were deposited at Bioprospecting Platform from the Laboratory of Chemistry of Natural Products. JA2, RA3, and RB3 extracts vouchers numbers are EX294, EX9355, and EX9356, respectively. For the experiments, they were resuspended in a solution of $1 \mathrm{~mL}$ Dulbecco's PBS containing 0.5\% DMSO. The extracts were tested using a single-blind method, i.e., the professional responsible to perform screening experiments did not know the name of biological species that originated the samples [31]. Because of this, they were named with a code.

\section{3 - Cell culture}

J774.G8 is a murine macrophage cell line that expresses P2 receptors. J774.G8 cell line was kindly provided by Dr. Vinícius Cotta from Laboratory on Thymus Research from Oswaldo Cruz Institute, Rio de Janeiro, Brazil. The cells were routinely maintained in culture with Dulbecco's Modified Eagle's Medium (DMEM) 
supplemented with $10 \%$ fetal bovine serum, at $37^{\circ} \mathrm{C}$ in a $5 \% \quad \mathrm{CO}_{2}$ atmosphere. The medium was changed every three days and the cells were adjusted to a concentration of $2 \times 10^{6}$ cells per $150 \mathrm{~cm}^{2}$ cell culture flask (Corning, New York, USA). Cell viability was analyzed by the trypan blue assay and the calcium assays were conducted only when the range of viability was above $90 \%$.

\section{4 - Calcium assays}

J774.G8 cells were plated in a concentration of $2 \times 10^{5}$ cells/well in a 96-well black-wall and clear-bottom plate (Corning, New York, USA), and maintained in culture with DMEM supplemented with $10 \%$ fetal bovine serum, at $37^{\circ} \mathrm{C}$ in a $5 \% \mathrm{CO}_{2}$ atmosphere for $24 \mathrm{~h}$. Subsequently, the medium was replaced by $100 \mu \mathrm{l}$ of Dulbecco's PBS (DPBS) (136 mM NaCl, $2.68 \mathrm{mM} \mathrm{KCl,} 8$ mM Na $2 \mathrm{HPO}_{4}, 1.46 \mathrm{mM} \mathrm{KH}_{2} \mathrm{PO}_{4}, 0.5$ $\mathrm{mM} \mathrm{MgCl}_{2}, 0.9 \mathrm{mM} \mathrm{CaCl} 2,5.55 \mathrm{mM}$ Glucose and $2.5 \mathrm{mM}$ Probenecid - $\mathrm{pH}$ 7.4) containing $[2 \mu \mathrm{M}]$ Fluo-4 AM and cells were incubated for 60 minutes at $37^{\circ} \mathrm{C}$ in a $5 \%$ $\mathrm{CO}_{2}$ atmosphere. Extracellular Fluo-4 was then removed by three consecutive washes with $200 \mu \mathrm{l}$ of DPBS and then, cells received a final volume of $150 \mu \mathrm{l}$ of DPBS. Cells were treated with antagonists for 30 minutes. The plate was then placed into the FlexStation III equipment (Molecular Devices, California, USA), which performed the addition of the agonists in each well, diluted in $50 \mu \mathrm{l}$ of DPBS. The mobilization of intracellular calcium was measured in real time prior, during and after the addition of the agonists at $\lambda$ (excitation): $485 \mathrm{~nm}$ and $\lambda$ (emission): $525 \mathrm{~nm}$. Total measurement runtime was 90 seconds and agonists were added at the time of 20 seconds. The readings were conducted every 1.52 seconds and a total of 60 readings were obtained for each well. The $\Delta F U$, i.e., the difference between fluorescence peak associated with the maximum concentration of intracellular calcium $\left(\left[\mathrm{Ca}^{2+}\right]_{\mathrm{i}}\right)$ and basal fluorescence of calcium was determined as mentioned in the study by Hansen and Bräuner-Osborne (2009) [28]. The wells which signal did not return to approximately $30 \%$ of the baseline after stimulation were discarded as control of quality.

\section{5 - Observation of cells loading in fluorescence microscope}

J774.G8 cells were load with Fluo-4 as previously described. Then, cells were observed in fluorescence microscope Nikon Eclipse TE 2000-S (Nikon, Tokyo, Japan), using 20X objectives. Fluo-4 was excited using a mercury lamp and a set of filters: exciter: 480/30 and barrier: 535/40. Ionomycin was added after $40 \mathrm{~s}$ of observation and 
pictures were captured with microscopy digital camera Infinity 3 (Lumenera, Ontario, Canada).

\section{6 - RNA extraction, RT-PCR and electrophoresis}

The mRNA was isolated from the J774.G8 cell line from a concentration of $5 \times 10^{6}$ cells using TRIzol (Life Technologies, California, USA), according to the manufacturer's specifications. Then, $20 \mu 1$ of mRNA was reverse transcribed at $42^{\circ} \mathrm{C}$ for 1 hour and at $70^{\circ} \mathrm{C}$ for 5 minutes using $1 \mu \mathrm{l}$ of reverse transcriptase enzyme. Next, $4 \mu \mathrm{l}$ of cDNA samples were used with $4 \mu \mathrm{l}$ of a primer sequence specific for each P2 receptor subtype, as shown in Table 2. These samples were used for the RT-PCR analysis in a $50 \mu \mathrm{l}$ reaction volume containing $5 \mu$ l of Buffer $10 \mathrm{x}, 4 \mu \mathrm{l} \mathrm{Mg}^{2+}, 0.4 \mu \mathrm{l}$ $\mathrm{dNTP}, 0.2 \mu \mathrm{l} \mathrm{Taq} \mathrm{polymerase} \mathrm{and} 4 \mu \mathrm{l}$ of water. Cycling conditions were: $94^{\circ} \mathrm{C}$ for 45 seconds, followed by 35 cycles of $54^{\circ} \mathrm{C}(\mathrm{P} 2 \mathrm{Y} 11), 55^{\circ} \mathrm{C}(\mathrm{P} 2 \mathrm{Y} 6), 57^{\circ} \mathrm{C}(\mathrm{P} 2 \mathrm{X} 1), 58^{\circ} \mathrm{C}$ (P2X3, P2Y14 and P2Y13), 60 ${ }^{\circ} \mathrm{C}$ (P2Y2, P2X2, P2X5, P2X6, P2Y12, P2Y1, P2Y4 and $\mathrm{GAPDH})$ or $65^{\circ} \mathrm{C}(\mathrm{P} 2 \mathrm{X} 4$ e $\mathrm{P} 2 \mathrm{X} 7)$ for 1 minute and $72^{\circ} \mathrm{C}$ for 45 seconds. PCR products were submitted to electrophoresis using a $2 \%$ agarose gel and visualized by ethidium bromide staining in a transilluminator.

Table 2 - Primer sequence of $\mathrm{P} 2$ receptors

\begin{tabular}{c|l}
\hline P2 receptor subtype & \multicolumn{1}{c}{ Primer sequence } \\
\hline P2X1 & $\begin{array}{l}\text { Forward: ATGTCCTCGGCATATTTGAA } \\
\text { Reverse: ATTGTGCAGAGAACCCAGAA }\end{array}$ \\
\hline P2X2 & $\begin{array}{l}\text { Forward: TTCATCGTGCAGAAAAGCTACC } \\
\text { Reverse: TGGATGCTGTTCTTGATGAGGA }\end{array}$ \\
\hline P2X3 & $\begin{array}{l}\text { Forward: CTTCACCTATGAGACCACCAAG } \\
\text { Reverse: CGGTATTTCTCCTCACTCTCTG }\end{array}$ \\
\hline P2X4 & $\begin{array}{l}\text { Forward: TGCTCATCCGCAGCCGCAAAGT } \\
\text { Reverse: AGTGGTCGCATCTGGAATCTCGG }\end{array}$ \\
\hline P2X6 & $\begin{array}{l}\text { Forward: ACTTCCCTGCAGAGTGCTGT } \\
\text { Reverse: GGCAGCTTTATCAAGGTCACA }\end{array}$ \\
\hline P2X7 & $\begin{array}{l}\text { Forward: TATGTGATGACCAGGAACTG } \\
\text { Reverse: CTCCAGATCTCACAGGTCCT }\end{array}$ \\
\hline P2Y1 & $\begin{array}{l}\text { Forward: GGCAGTTCAGGGAGGAATCATGG } \\
\text { Reverse: AAGCGCCAGGTGGCATAGCTC }\end{array}$ \\
\hline & $\begin{array}{l}\text { Forward: CTGTTGAGACTTGCTAGACCTC } \\
\text { Reverse: ATGTTCAATTTGCTCTGGC }\end{array}$ \\
\hline
\end{tabular}




\begin{tabular}{c|l}
\hline P2Y4 & $\begin{array}{l}\text { Forward: TGGCATTGTCAGACACCTTG } \\
\text { Reverse: AAGCAGACAGCAAAGACAGTC }\end{array}$ \\
\hline P2Y6 & $\begin{array}{l}\text { Forward: CGCTTCCTCTTCTATGCCAA } \\
\text { Reverse: GTAGGCTGTCTTGGTGATGTG }\end{array}$ \\
\hline P2Y11 & $\begin{array}{l}\text { Forward: CAGCGTCATCTTCATCACC } \\
\text { Reverse: GCTATACGCTCTGTAGGC }\end{array}$ \\
\hline P2Y12 & $\begin{array}{l}\text { Forward: CTGCCAAGTCATTTTCTGGA } \\
\text { Reverse: AGCATGCTCATCAAGGAATTT }\end{array}$ \\
\hline P2Y14 & $\begin{array}{l}\text { Forward: AGGGGTTTTGTGTGCACTTT } \\
\text { Reverse: CTGACTGCTGTGGTGCTCAT }\end{array}$ \\
\hline GAPDH & $\begin{array}{l}\text { Forward: GCTGTCCCCAACATCATTCT } \\
\text { Reverse: GTTTTGGGGAACTCGCAGA }\end{array}$ \\
\hline & $\begin{array}{l}\text { Forward: ATCACCATCTTCCAGGAGCG } \\
\text { Reverse: CCTGCTTCACCACCTTCTTG }\end{array}$ \\
\hline
\end{tabular}

\section{7 - Animals}

The experiments with animals were approved by Ethics Committee on the use of Animals from Oswaldo Cruz Institute under identification code L-037/2017, approved on November 242017 and follow ethical principles in animal experimentation of Brazilian College of Animal Experimentation. Healthy male C57BL/6 mice with a weight between 25 and 30g were obtained from Oswaldo Cruz Central Bioterium. The animals were housed under conditions of $12 \mathrm{~h} / 12 \mathrm{~h}$ light and dark cycle with free access to food and water.

\section{8 - Peritoneal macrophage isolation}

Animals were euthanized by $\mathrm{CO}_{2}$ asphyxiation. Then, $5 \mathrm{~mL}$ of RPMI medium was injected into the peritoneal cavity. Peritoneal cells were collected and macrophages were isolated by centrifugation at $1500 \mathrm{RPM}$ for 10 minutes. Cell viability was analyzed by the trypan blue assay. Peritoneal macrophages were plated in a concentration of $4 \times 10^{5}$ cells/well in a 96-well black-wall and clear-bottom plate and maintained in culture with RPMI supplemented with $10 \%$ fetal bovine serum, at $37^{\circ} \mathrm{C}$ in a $5 \% \quad \mathrm{CO}_{2}$ atmosphere for $24 \mathrm{~h}$. Calcium assays were conducted using the same conditions previously described. 


\section{9 - Cell viability measurement}

J774.G8 cells were plated in a concentration of $2 \times 10^{5}$ cells/well in a 96-well plate (Corning, New York, USA), and maintained in culture with DMEM supplemented with $10 \%$ fetal bovine serum, at $37^{\circ} \mathrm{C}$ in a $5 \% \mathrm{CO}_{2}$ atmosphere for $24 \mathrm{~h}$. Next, cells were treated with extracts [50 $\mu \mathrm{g} / \mathrm{mL}]$ and antagonists PPADS [300 $\mu \mathrm{M}]$ and RB-2 [20 $\mu \mathrm{M}]$ for 1,6 or $24 \mathrm{~h}$. Cells treated with Triton-x $(0.1 \%)$ were considered as a negative control of viability, while our positive control was obtained with a cell that did not receive any treatment. Subsequently, the medium was replaced by $180 \mu \mathrm{l}$ of DMEM without phenol red and each well received a volume of $20 \mu \mathrm{l}$ of MTT solution [100 $\mu \mathrm{g} / \mathrm{well}]$ and the plate was incubated for $3 \mathrm{~h}$ at $37^{\circ} \mathrm{C}$ in a $5 \% \mathrm{CO}_{2}$ atmosphere. After this time, the plate was centrifuged at 1500 RPM for 1 minute. Then, supernatants were collected and formazan crystals were dissolved in $100 \mu 1$ of DMSO as described [32]. The absorbance of the wells was measured in FlexStation III equipment, using $\lambda$ : 570 $\mathrm{nm}$.

\subsection{0 - Data analysis}

Each sample was measured in triplicate and all experiments were performed on at least three independent days. All data are presented as means \pm S.D.M., while the curves are presented as means \pm S.E.M. In order to test if samples follow a Gaussian distribution, the D' Agostino and Pearson normality test was used. If data follow a Gaussian distribution, an appropriate parametric test was applied, if not, an appropriate non-parametric test was applied. Used tests were specified in figure legends. P values of 0.05 or less were considered significant. Graphs and statistical analyses were performed by GraphPad Prism version 7 (GraphPad Software, San Diego, California, USA). We also assessed the quality of our calcium assay by calculating the $z^{\prime}$-factor. $Z$ '-factor is a valuable tool to evaluate the robustness and suitability of HTS assays. Z'-factor values above 0.5 consider assay as excellent and equal a 1 , an ideal assay. However, values below 0.5 , consider assay as a double assay that needs to be reformulated [33]. This parameter was calculated using the following equation:

$$
Z^{\prime}=1-\frac{(3 \mathrm{SD} \text { of positive control }+3 \mathrm{SD} \text { of negative control })}{(\text { mean of positive control }- \text { mean of negative control })}
$$


where cells stimulated with UTP at $[10 \mu \mathrm{M}]$ were considered as a positive control (concentration used in screening experiments), while cells stimulated with DPBS only were considered as negative control.

\section{Acknowledgments}

This work was supported by grants from Fundação de Amparo à Pesquisa do Estado do Rio de Janeiro (FAPERJ), Conselho Nacional de Desenvolvimento Científico e Tecnológico (CNPq) and Instituto Oswaldo Cruz (IOC). We thank Dr. Vinícius Cotta, who kindly gifted us with J774.G8 cell line and Fátima Regina Marques for technical assistance with extracts.

\section{Author Contributions}

Luiz Alves, Rômulo Bezerra, and Natiele Ferreira conceived and designed the experiments; Natiele Ferreira, Rebeca Silveira, Clayton Silva, Carla Santos and Andrea Calheiros performed the experiments; Natiele Ferreira, Rômulo Bezerra, Carla Santos and Luiz Alves analyzed and interpreted the data; Tânia Alves and Carlos Zani contributed with samples of extracts; Natiele Ferreira and Luiz Alves wrote the paper.

\section{Conflict of interest}

The authors declare that there is no conflict of interest.

\section{References}

1. Ralevic, V.; Burnstock, G. Receptors for purines and pyrimidines. Pharmacol. Rev. 1998, 50, 413-492, doi:10.1007/978-3-642-28863-0_5.

2. Jacobson, K. A.; Boeynaems, J.-M. P2Y nucleotide receptors: promise of therapeutic applications. Drug Discov. Today 2010, 15, 570-8, doi:10.1016/j.drudis.2010.05.011.

3. Peterson, T. S.; Camden, J. M.; Wang, Y.; Seye, C. I.; Wood, W. G.; Sun, G. Y.; Erb, L.; Petris, M. J.; Weisman, G. A. P2Y2 nucleotide receptor-mediated responses in brain cells. Mol. Neurobiol. 2010, 41, 356-66, doi:10.1007/s12035010-8115-7.

4. Burnstock, G. Pathophysiology and Therapeutic Potential of Purinergic Signalling. Pharmacol. Rev. 2006, 58, 58-86, doi:10.1124/pr.58.1.5.58.

5. Lau, O. C. F.; Samarawickrama, C.; Skalicky, S. E. P2Y2 receptor agonists for the treatment of dry eye disease: a review. Clin. Ophthalmol. 2014, 8, 327-34, doi:10.2147/OPTH.S39699.

6. Nakamura, M.; Imanaka, T.; Sakamoto, A. Diquafosol Ophthalmic Solution for Dry Eye Treatment. Adv. Ther. 2012, 29, 579-589, doi:10.1007/s12325-0120033-9. 
7. Weisman, G. A.; Wang, M.; Kong, Q.; Chorna, N. E.; Neary, J. T.; Sun, G. Y.; González, F. A.; Seye, C. I.; Erb, L. Molecular Determinants of P2Y2 Nucleotide Receptor Function: Implications for Proliferative and Inflammatory Pathways in Astrocytes. Mol. Neurobiol. 2005, 31, 169-184, doi:10.1385/MN:31:1-3:169.

8. Jacob, F.; Pérez Novo, C.; Bachert, C.; Van Crombruggen, K. Purinergic signaling in inflammatory cells: P2 receptor expression, functional effects, and modulation of inflammatory responses. Purinergic Signal. 2013, 9, 285-306, doi:10.1007/s11302-013-9357-4.

9. Thevananther, S.; Sun, H.; Li, D.; Arjunan, V.; Awad, S. S.; Wyllie, S.; Zimmerman, T. L.; Goss, J. A.; Karpen, S. J. Extracellular ATP activates c-jun N-terminal kinase signaling and cell cycle progression in hepatocytes. Hepatology 2004, 39, 393-402, doi:10.1002/hep.20075.

10. Tackett, B. C.; Sun, H.; Mei, Y.; Maynard, J. P.; Cheruvu, S.; Mani, A.; Hernandez-Garcia, A.; Vigneswaran, N.; Karpen, S. J.; Thevananther, S. P2Y2 purinergic receptor activation is essential for efficient hepatocyte proliferation in response to partial hepatectomy. Am. J. Physiol. - Gastrointest. Liver Physiol. 2014, 307.

11. Degagné, E.; Grbic, D. M.; Dupuis, A.-A.; Lavoie, E. G.; Langlois, C.; Jain, N.; Weisman, G. A.; Sévigny, J.; Gendron, F.-P. P2Y2 receptor transcription is increased by NF-kappa B and stimulates cyclooxygenase-2 expression and PGE2 released by intestinal epithelial cells. J. Immunol. 2009, 183, 4521-9, doi:10.4049/jimmunol.0803977.

12. Zhang, Y.; Kohan, D. E.; Nelson, R. D.; Carlson, N. G.; Kishore, B. K. Potential involvement of $\mathrm{P} 2 \mathrm{Y} 2$ receptor in diuresis of postobstructive uropathy in rats. Am. J. Physiol. Renal Physiol. 2010, 298, F634--42, doi:10.1152/ajprenal.00382.2009.

13. Vanderstocken, G.; Bondue, B.; Horckmans, M.; Di Pietrantonio, L.; Robaye, B.; Boeynaems, J.-M.; Communi, D. P2Y2 receptor regulates VCAM-1 membrane and soluble forms and eosinophil accumulation during lung inflammation. $J$. Immunol. 2010, 185, 3702-3707, doi:10.4049/jimmunol.0903908.

14. Ayata, C. K.; Ganal, S. C.; Hockenjos, B.; Willim, K.; Vieira, R. P.; Grimm, M.; Robaye, B.; Boeynaems, J. M.; Di Virgilio, F.; Pellegatti, P.; Diefenbach, A.; Idzko, M.; Hasselblatt, P. Purinergic P2Y2 receptors promote neutrophil infiltration and hepatocyte death in mice with acute liver injury. Gastroenterology 2012, 143, 1620-1629.e4, doi:10.1053/j.gastro.2012.08.049.

15. Inoue, Y.; Chen, Y.; Hirsh, M. I.; Yip, L.; Junger, W. G. A3 and P2Y2 Receptors Control the Recruitment of Neutrophils To the Lungs in a Mouse Model of Sepsis. Shock 2008, 30, 1, doi:10.1097/shk.0b013e318160dad4.

16. Marcus, D. C.; Scofield, M. A. Apical P2Y4 purinergic receptor controls K+ secretion by vestibular dark cell epithelium. Am. J. Physiol. Cell Physiol. 2001, 281, C282-9.

17. Ghanem, E.; Robaye, B.; Leal, T.; Leipziger, J.; Van Driessche, W.; Beauwens, R.; Boeynaems, J.-M. The role of epithelial P2Y2 and P2Y4 receptors in the regulation of intestinal chloride secretion. Br. J. Pharmacol. 2005, 146, 364-9, doi:10.1038/sj.bjp.0706353.

18. Kim, C.-H.; Kim, H.-Y.; Lee, H. S.; Chang, S. O.; Oh, S.-H.; Lee, J. H. P2Y4Mediated Regulation of $\mathrm{Na}+$ Absorption in the Reissner's Membrane of the Cochlea. J. Neurosci. 2010, 30, 3762-3769, doi:10.1523/JNEUROSCI.330009.2010.

19. Maruoka, H.; Jayasekara, M. P. S.; Barrett, M. O.; Franklin, D. A.; de Castro, S.; 
Kim, N.; Costanzi, S.; Harden, T. K.; Jacobson, K. A. Pyrimidine nucleotides with 4-alkyloxyimino and terminal tetraphosphate $\delta$-ester modifications as selective agonists of the P2Y(4) receptor. J. Med. Chem. 2011, 54, 4018-33, doi:10.1021/jm101591j.

20. Koehn, F. E.; Carter, G. T. The evolving role of natural products in drug discovery. Nat. Rev. Drug Discov. 2005, 4, 206-220, doi:10.1038/nrd1657.

21. Balunas, M. J.; Kinghorn, A. D. Drug discovery from medicinal plants. Life Sci. 2005, 78, 431-441, doi:10.1016/j.lfs.2005.09.012.

22. Itokawa, H.; Morris-Natschke, S. L.; Akiyama, T.; Lee, K.-H. Plant-derived natural product research aimed at new drug discovery. J. Nat. Med. 2008, 62, 263-280, doi:10.1007/s11418-008-0246-z.

23. Galvez-Llompart, M.; Zanni, R.; García-Domenech, R. Modeling natural antiinflammatory compounds by molecular topology. Int. J. Mol. Sci. 2011, 12, 9481-503, doi:10.3390/ijms12129481.

24. Liu, L.; Zou, J.; Liu, X.; Jiang, L.-H.; Li, J. Inhibition of ATP-induced macrophage death by emodin via antagonizing $\mathrm{P} 2 \mathrm{X} 7$ receptor. Eur. $J$. Pharmacol. 2010, 640, 15-19, doi:10.1016/j.ejphar.2010.04.036.

25. Santos, J. A. A.; Fidalgo-Neto, A. A.; Faria, R. X.; Simões, A.; Calheiros, A. S.; Bérenger, A. L.; Faria-Neto, H. C. C.; Figueiredo, M. R.; Frutuoso, V. S. L.; Alves, L. A. Effect of Rheedia longifolia leaf extract and fractions on the P2X7 receptor in vitro: novel antagonists? J. Med. Food 2011, 14, 920-9, doi:10.1089/jmf.2010.0184.

26. Arkin, M. R.; Connor, P. R.; Emkey, R.; Garbison, K. E.; Heinz, B. A.; Wiernicki, T. R.; Johnston, P. A.; Kandasamy, R. A.; Rankl, N. B.; Sittampalam, S. FLIPR ${ }^{T M}$ Assays for GPCR and Ion Channel Targets; Eli Lilly \& Company and the National Center for Advancing Translational Sciences, 2004;

27. Sullivan, E.; Tucker, E. M.; Dale, I. L. Measurement of $[\mathrm{Ca} 2+]$ using the Fluorometric Imaging Plate Reader (FLIPR). Methods Mol. Biol. 1999, 114, 12533, doi:10.1385/1-59259-250-3:125.

28. Hansen, K. B.; Bräuner-Osborne, H. FLIPR assays of intracellular calcium in GPCR drug discovery. Methods Mol. Biol. 2009, 552, 269-78, doi:10.1007/9781-60327-317-6_19.

29. Kaulich, M.; Streicher, F.; Mayer, R.; Müller, I.; Müller, C. E. Flavonoids - novel lead compounds for the development of $\mathrm{P} 2 \mathrm{Y}_{2}$ receptor antagonists. Drug Dev. Res. 2003, 59, 72-81, doi:10.1002/ddr.10203.

30. Ito, M.; Egashira, S.; Yoshida, K.; Mineno, T.; Kumagai, K.; Kojima, H.; Okabe, T.; Nagano, T.; Ui, M.; Matsuoka, I. Identification of novel selective P2Y 6 receptor antagonists by high-throughput screening assay. Life Sci. 2017, 180, 137-142, doi:10.1016/j.lfs.2017.05.017.

31. Salkind, N. Single-Blind Study. Encycl. Res. Des. 2010.

32. Huang, T. T.; Ojcius, D. M.; Young, J. D.; Wu, Y. H.; Ko, Y. F.; Wong, T. Y.; Wu, C. Y.; Lu, C. C.; Lai, H. C. The anti-tumorigenic mushroom agaricus blazei murill enhances IL-1 $\beta$ production and activates the NLRP3 inflammasome in human macrophages. PLoS One 2012, 7, 1-11, doi:10.1371/journal.pone.0041383.

33. Zhang, J.-H.; Chung; Oldenburg A simple statistical parameter for use in evaluation and validation of high throughput screening assays. J. Biomol. Screen. 1999, 4, 67-73, doi:10.1177/108705719900400206.

34. Molecular Devices Measuring Intracellular Calcium with the FLIPR I and FLIPR 384 Fluorometric Imaging Plate Reader Systems Available online: 
https://www.moleculardevices.com/resources/application-notes/measuringintracellular-calcium-flipr-i-and-flipr-384-fluorometric (accessed on Jul 21, 2017).

35. Luo, J.; Zhu, Y.; Zhu, M. X.; Hu, H. Cell-based calcium assay for medium to high throughput screening of TRP channel functions using FlexStation 3. J. Vis. Exp. 2011, doi:10.3791/3149.

36. Camarda, V.; Fischetti, C.; Anzellotti, N.; Molinari, P.; Ambrosio, C.; Kostenis, E.; Regoli, D.; Trapella, C.; Guerrini, R.; Severo, S.; Calo, G. Pharmacological profile of NOP receptors coupled with calcium signaling via the chimeric protein Gaqi5. Naunyn. Schmiedebergs. Arch. Pharmacol. 2009, 379, 599-607, doi:10.1007/s00210-009-0396-X.

37. Namovic, M. T.; Jarvis, M. F.; Donnelly-Roberts, D. High Throughput Functional Assays for P2X Receptors. In Current Protocols in Pharmacology; John Wiley \& Sons, Inc.: Hoboken, NJ, USA, 2012; Vol. Chapter 9, p. Unit 9.15.

38. Accurso, F. J.; Moss, R. B.; Wilmott, R. W.; Anbar, R. D.; Schaberg, A. E.; Durham, T. A.; Ramsey, B. W. Denufosol Tetrasodium in Patients with Cystic Fibrosis and Normal to Mildly Impaired Lung Function. Am. J. Respir. Crit. Care Med. 2011, 183, 627-634, doi:10.1164/rccm.201008-1267OC.

39. Li, X.; Llorente, I.; Brasch, M. Improvements in live cell analysis of G protein coupled receptors using second generation BD calcium assay kits. Curr. Chem. Genomics 2008, 2, 10-5, doi:10.2174/1875397300802010010.

40. Gee, K. R.; Brown, K. A.; Chen, W.-N. U.; Bishop-Stewart, J.; Gray, D.; Johnson, I. Chemical and physiological characterization of fluo-4 Ca2+-indicator dyes. Cell Calcium 2000, 27, 97-106, doi:10.1054/ceca.1999.0095.

41. Valentin, S.; Ortmann, B.; Atze, K.; Breuer, N.; Franke, S.; Kühn, M.; Faust, N. New Tools for Drug Discovery: Monitoring Intracellular $\mathrm{Ca} 2+$ Fluxes in Primary Cell Types with High-Throughput Formats 2011.

42. Buell, G.; Michel, A.; Lewis, C.; Collo, G.; Humphrey, P.; Surprenant, A. P2X1 receptor activation in HL60 cells. Blood 1996, 87.

43. Adrian, K.; Bernhard, M. K.; Breitinger, H. G.; Ogilvie, A. Expression of purinergic receptors (ionotropic P2X1-7 and metabotropic P2Y1-11) during myeloid differentiation of HL60 cells. Biochim. Biophys. Acta 2000, 1492, 12738.

44. Coutinho-Silva, R.; Ojcius, D. M.; Górecki, D. C.; Persechini, P. M.; Bisaggio, R. C.; Mendes, A. N.; Marks, J.; Burnstock, G.; Dunn, P. M. Multiple P2X and $\mathrm{P} 2 \mathrm{Y}$ receptor subtypes in mouse $\mathrm{J} 774$, spleen and peritoneal macrophages. Biochem. Pharmacol. 2005, 69, 641-655, doi:10.1016/j.bcp.2004.11.012.

45. Sakaki, H.; Tsukimoto, M.; Harada, H.; Moriyama, Y.; Kojima, S. Autocrine regulation of macrophage activation via exocytosis of ATP and activation of P2Y11 receptor. PLoS One 2013, 8, e59778, doi:10.1371/journal.pone.0059778.

46. Azimi, I.; Roberts-Thomson, S. J.; Monteith, G. R. Calcium influx pathways in breast cancer: opportunities for pharmacological intervention. Br. J. Pharmacol. 2014, 171, 945-960, doi:10.1111/bph.12486.

47. King, B. F.; Townsend-Nicholson, A.; Burnstock, G.; King, B. F.; TownsendNicholson, A.; Burnstock, G. Metabotropic receptors for ATP and UTP: exploring the correspondence between native and recombinant nucleotide receptors. 1998, 19.

48. von Kügelgen, I. Pharmacological profiles of cloned mammalian P2Y-receptor subtypes. Pharmacol. Ther. 2006, 110, 415-432, doi:10.1016/j.pharmthera.2005.08.014. 